Journal of Futures Markets, forthcoming

\title{
Speculative Pressure
}

\author{
John Hua Fan ${ }^{\dagger}$, Adrian Fernandez-Perez ${ }^{\ddagger}$, Ana-Maria Fuertes ${ }^{\S}$ and Joëlle Miffre ${ }^{\rrbracket}$
}

\begin{abstract}
The paper investigates the information content of speculative pressure across futures classes. Longshort portfolios of futures contracts sorted by speculative pressure capture a significant premium in commodity, currency and equity markets but not in fixed income markets. Exposure to commodity, currency and equity index futures' speculative pressure is priced in the broad crosssection after controlling for momentum, carry, global liquidity and volatility risks. The findings are confirmed by robustness tests using alternative speculative pressure signals, portfolio construction techniques and sub-periods inter alia. We argue that there is an efficient hedgersspeculators risk transfer in commodity, currency and equity index futures markets.
\end{abstract}

JEL classifications: G13, G14

Keywords: Speculative pressure, Risk premium, Pricing, Futures markets

† Senior Lecturer in Finance, Griffith Business School, Griffith University. 170 Kessels Road, Brisbane, Australia; Tel + 61 (0)7 3735 4638; e-mail: j.fan@griffith.edu.au

¥ $\quad$ Research Fellow, Auckland University of Technology, Private Bag 92006, 1142 Auckland, New Zealand; Tel: +64 (0)9 921 9999; e-mail: adrian.fernandez@aut.ac.nz. Corresponding author

$\S \quad$ Professor of Finance and Econometrics, Cass Business School, City University of London, ECIY 8TZ, United Kingdom; Tel: +44 (0)20 7040 0186; e-mail: a.fuertes@city.ac.uk

ๆ Professor of Finance, Audencia Business School, 8 Route de la Jonelière, 44312, Nantes, France; Tel: +33 (0)2 403734 34; e-mail: jmiffre@audencia.com

We gratefully acknowledge financial support from Europlace Institute of Finance, Institut Louis Bachelier and Griffith Centre for Personal Finance and Superannuation. Parts of the paper were completed while J. Fan was visiting Audencia Business School. We would like to thank the Editor, Robert Webb, an anonymous referee, as well as G. Bagnarosa, D. Basu, D. Kuruppuarachchi, H.Till, R. Zhang (data collection), and participants at research seminars at University College Dublin, Rennes School of Business and at the INFINITI 2018 conference on International Finance, Derivative Markets Conference 2018, PANORisk Conference 2018, Australasian Commodity Markets Conference 2019 and Conference on Computational and Financial Econometrics 2019. 


\section{Introduction}

A well-established theory on commodity futures pricing hinges on the hedging pressure hypothesis of Cootner (1960) and Hirshleifer (1988). ${ }^{1}$ The key contention of this 'insurance mechanism' theory is that the prices of commodity futures are driven by the net positions of hedgers and speculators. When hedgers are net short, futures prices are low relative to their expected values at maturity to entice net long speculation, a market condition known as backwardation. When hedgers are net long, futures prices are high relative to their expected values at maturity to induce net short speculation, which is known as contango. Accordingly, by taking opposite positions to those of hedgers, speculators earn a premium as compensation for bearing the price risk of hedgers.

The theoretical motivation for the hedging pressure hypothesis is largely confined to commodities, however, it is possible that speculative (hedging) pressure influences the price formation process in other futures markets. Firms that issue and invest in foreign currency-denominated securities or that engage in cross-border trades typically want to hedge their foreign exchange exposure. Likewise, ahead of an anticipated market fluctuation, fixed income and equity managers may want to tactically hedge their spot exposure by taking an opposite position in futures markets. Asset managers and index providers may need to hedge their products in the face of customers' early redemptions. In all these financial futures markets too, speculators may claim a premium as insurance suppliers. Using as signal the past net long positions of large non-commercial participants over their total positions (speculative pressure signal, hereafter), we test this conjecture

\footnotetext{
${ }^{1}$ The hedging pressure hypothesis generalizes the normal backwardation theory of Keynes (1930) and Hicks (1939). Normal backwardation argues that hedgers are normally net short as commodity producers are more prone to hedge their price risk than commodity consumers.
} 
by conducting empirical tests of whether speculators receive a premium for shouldering the price risk of hedgers in commodity, currency, equity index and fixed income futures markets.

For this purpose, we begin by constructing fully-collateralized portfolios that take long (short) positions in the futures with the most positive (negative) speculative pressure. To our best knowledge, no other paper in the literature studies the performance and risk profile of long-short speculative pressure portfolios in futures markets for instruments beyond commodities. Thus, we extend the portfolio study of Basu and Miffre (2013) to currency, equity and fixed income futures markets. We investigate the nature of the speculative pressure risk premium thus captured in the context of 'everywhere' tradeable factors based on general market movements - the momentum and value factors documented in Asness et al. (2013) and the carry factor of Koijen et al. (2018). Next, we seek to understand the drivers of the speculative pressure risk premia across futures classes by testing for the presence of a common structure. Finally, we address the question of whether exposure to the class-specific and 'everywhere' speculative pressure factor is priced in the broad cross-section of futures returns, while controlling for various (non-)tradeable factors. ${ }^{2}$

The findings suggest that an efficient risk transfer mechanism from hedgers to speculators is at play not only in commodity futures markets but also in currency and equity futures markets. The longshort portfolio analysis reveals that speculators in these markets earn statistically significant mean excess returns that range from $2.51 \%$ to $4.12 \%$ per annum as a reward for providing price risk insurance to hedgers. The cross-sectional pricing analysis reveals that the speculative pressure risk factors constructed either, individually, within each commodity, currency and equity index futures

${ }^{2}$ In our paper, the term 'everywhere' is used to refer to diverse classes of futures contracts. Investigating the issue of whether the 'everywhere' speculative pressure premium constructed from futures data can price the cross-section of stocks or bonds goes beyond the scope of this paper. 
market or jointly across markets ('everywhere' speculative pressure factor) can explain the broad cross-section of futures returns across classes after controlling for the corresponding class-specific or 'everywhere' tradeable momentum, value and carry factors, and non-tradeable macroeconomic, global liquidity and volatility risks. The findings are not driven by transaction costs or illiquidity and remain robust also to the consideration of alternative speculative pressure signals, portfolio construction techniques, ranking and holding periods and sub-periods.

In sharp contrast, we find no evidence of a significant speculative pressure premium in the interest rate and fixed income futures markets. Thus, albeit from the lens of different research questions, our paper reaffirms Bessembinder (1992) and Moskowitz et al. (2012) in establishing that fixed income futures markets behave differently from other futures markets as regards the information content of the net positions of hedgers or speculators. ${ }^{3}$ A hedgers-to-speculators risk transfer in fixed income futures markets would be obscured if agents choose to hedge their interest rate risk with other strategies (i.e., immunization, temporary change in modified duration).

The article contributes to the literature in three ways. First, to our knowledge, it provides the first empirical investigation of the ability of tradeable long-short portfolios based on speculative pressure to capture premia in futures markets on instruments beyond commodities. In so doing, we add to Bessembinder (1992) and de Roon et al. (2000) who also study the pricing of hedging or speculative pressure in various futures markets. However, unlike us, they do not assess the extent

${ }^{3}$ Bessembinder (1992) finds that residual risk conditioned on net hedging or speculative positions has strong cross-sectional explanatory power for agricultural and currency futures returns, while Moskowitz et al. (2012) document a relatively weak nexus between net speculative positions and time-series momentum in fixed income futures markets. In a different vein, the carry study across futures markets in Koijen et al. (2018) also documents weaker results for fixed income instruments. 
to which it is possible to capture a premium through long-short speculative pressure portfolios. ${ }^{4}$ This portfolio analysis facilitates fresh evidence to inform an ongoing debate on whether hedging pressure and its corollary, speculative pressure, matter to the pricing of commodity futures. ${ }^{5}$ It also allows us to go a step further by addressing for the first time the same question via a long-short portfolio analysis for three distinct cross-sections of financial futures contracts.

Second, by investigating the cross-market performance of speculative pressure portfolios across classes of futures contracts, we contribute to an 'everywhere' pricing literature that has so far focused on the momentum, value and carry factors. ${ }^{6}$ In this line of research, our study is the first to seek to identify the presence of common driving factors behind the cross-class speculative pressure premia. Thus, our empirical analysis informs not only the literature on asset pricing across futures classes, but also market participants interested in designing practical investment solutions that are effective across futures classes.

Finally, our research adds to a literature that investigates the potentially harmful impact of speculators on futures prices (Irwin et al., 2009; Stoll and Whaley, 2010; Fattouh et al., 2013).

${ }^{4}$ Another difference pertains to the sample. On the one hand, the broad cross-section of futures markets that we examine ( $N=84)$, compared to the 22 contracts in Bessembinder (1992) and 20 contracts in de Roon et al. (2000), should enable firmer evidence on the hedging pressure hypothesis. On the other hand, the time span from 1993 until 2018 includes recent important landmarks which should enable more up-to-date tests.

${ }^{5}$ A positive relation between the net short (long) positions of hedgers (speculators) and commodity futures returns has been documented by Cootner (1960, 1967), Chang (1985), Hirshleifer (1988, 1989), Bessembinder (1992), de Roon et al. (2000), Dewally et al. (2013), and Basu and Miffre (2013), whereas in sharp contrast, Rouwenhorst and Tang (2012), Gorton et al. (2013), Daskalaki et al. (2014), and Szymanowska et al. (2014) find no evidence of a significant relation.

${ }^{6}$ The so-called 'everywhere' literature suggests that a given asset characteristic has time-series and/or cross-sectional pricing ability across asset classes; e.g., the momentum and value as documented in Asness et al. (2013), and the carry or basis established by Koijen et al. (2018). 
Finding that equity index, currency and commodity futures markets facilitate risk transfer and reward suggests that calls to regulate excessive speculation are unwarranted; speculators do not destabilize these futures markets, rather they are important providers of liquidity and risk bearing facility to hedgers. Vice versa, our finding that the fundamental risk transfer mechanism is insignificant in fixed income futures markets could call for more unequivocal conceptualizations of hedging versus speculative trades and/or increased monitoring of the positions of market participants as regards the accuracy of their declarations as hedgers or speculators.

The rest of the article unfolds as follows. Section 2 presents the speculative pressure signal and the data. Sections 3 and 4 describe the time-series and cross-sectional tests and the corresponding results. Section 5 implements a battery of robustness checks and finally, Section 6 concludes.

\section{Speculative Pressure Signal and Data}

We measure the speculative pressure of each futures instrument $i=1, \ldots, N$ at each month end $t$ as the average of past weekly net positions of speculators relative to their total positions. Formally

$$
S P_{i, t}=\frac{1}{W} \sum_{w=1}^{W} \frac{L_{i, w}-S_{i, w}}{L_{i, w}+S_{i, w}}
$$

where $L_{i, w}$ and $S_{i, w}$ are the week $w$ long and short open interest of large non-commercial traders (also known as speculators) on aggregate along the entire futures curve, as explained next, and $W$ is the length (in weeks) of the lookback window. We use $W=52$ (yearly window) for the reasons given below. The futures price is expected to rise as maturity approaches in a backwardated market, that is, where $S P_{i, t}>0$, to reward net long speculators for providing insurance to net short hedgers. Vice versa, the futures price is expected to fall with maturity when the market is in contango $\left(S P_{i, t}<0\right)$ to reward speculators for being net short in order to accommodate net long hedging 
demands. A similar speculative pressure signal is used previously by Basu \& Miffre (2013), Moskowitz et al. (2012), and Dewally et al. (2013) inter alia.

Every Tuesday, large market participants must declare to the Commodity Futures Trading Commission (CFTC) the motives (hedging for commercial traders or speculation for noncommercial traders) and the nature (long or short) of their futures positions. The CFTC aggregates the positions along the futures curve for each underlying asset and for each type of traders (long commercials, short commercials, long non-commercials and short non-commercials), and publishes the four resulting aggregated open interest measures in its Futures-Only Legacy Commitments of Traders (COT) report on Friday of the same week. The two variables, $L_{i, w}$ and $S_{i, w}$, used in Equation (1) correspond to the latter two measures. Even though the CFTC verifies the declarations of market participants, we recognize that futures trading motives are not always easy to classify as speculators may behave at times as hedgers and hedgers can also engage in speculation (Anderson and Danthine, 1983; Stulz, 1984; Ederington and Lee, 2002). Therefore, we acknowledge that the proxy of the phases of backwardation and contango encapsulated in the $S P_{i, t}$ signal might be noisy but it should not contain any systematic error (i.e., zero mean error).

The choice of a relatively long (one year) lookback window to measure the speculative signal through Equation (1) should allow us to capture the long-run, smooth fluctuations in the supply and demand of commodities, currencies, equity indices and fixed income securities that are related to production and business cycles. These smooth fluctuations, in turn, trigger slow variations in hedging demand and, consequently, slow variations in speculative supply. Motivated by the evidence provided by Kang et al. (2019) in the context of commodity futures, the choice of a yearly lookback period may also help mitigate the noise associated with the short-term liquidity demands 
of 'impatient' speculators that induce variations in the positions of market participants that are unrelated to hedging pressure.

The cross-section of 84 futures instruments (43 commodities, 11 currencies, 19 equity indices and 11 fixed income and interest rates) and time period covered by our sample (from September 30, 1992 to May 25, 2018) are dictated by the availability of CFTC open interest data. The empirical analysis requires also the daily settlement prices of each futures contract which we obtain from Thomson Reuters Datastream. We measure futures returns as the logarithmic price changes of the front-end contracts up to one month before maturity; the positions are then rolled to the secondnearest contract. As the CFTC publishes the aggregate open interest measures $L_{i, w}$ and $S_{i, w}$ each week on Friday, we cautiously match the Friday announcements with subsequent futures prices changes, i.e., we consider the release date as the date of the traders’ positions.

\section{[Insert Table 1 around here]}

Table 1 reports per asset the mean and standard deviation of excess returns and speculative pressure measured at each sample month-end, $S P_{i, t}$, from Equation (1). These summary statistics reveal large heterogeneity particularly within asset classes. The table also shows the frequency with which speculators are net long; that is, the percentage of sample months when $S P_{i, t}>0$. These frequencies suggest that there is a slight propensity for futures markets to be in backwardation; namely, we observe that $S P_{i, t}>0$ in $71 \%, 65 \%, 60 \%$ and $52 \%$ of the sample months on average for commodity, currency, equity index and fixed income futures, respectively. This summary statistics confirm that large speculators (generally, investment banks, hedge funds, CTAs) are, typically net long while large hedgers are typically net short. However, there is large within class heterogeneity in this regard too; namely, some futures are persistently in backwardation (e.g., coal, 
Russian ruble, NYSE composite index and 90-day T-bill futures), while others are more often than not in contango (e.g., cheese, Swiss franc, S\&P 500 index and 10-year agency notes futures).

\section{Long-short Speculative Pressure Portfolios}

\subsection{Methodology}

Our portfolio construction approach begins by measuring at each month end $t$ the standardized speculative pressure signal $\omega_{i, t} \equiv\left(S P_{i, t}-\overline{S P}_{t}\right) / \sigma_{S P, t}$ per futures contract $i=1, \ldots, N$ where $S P_{i, t}$ is as defined in Equation (1), and $\overline{S P}_{t}$ and $\sigma_{S P, t}$ are the corresponding cross-sectional mean and standard deviation. As implied by the hedging pressure hypothesis, the portfolio strategy takes long positions in futures contracts with positive $\omega_{i, t}$ (i.e., those that are most likely in backwardation) and short positions in futures contracts with negative $\omega_{i, t}$ (i.e., those that are most likely in contango). The weight of each futures contract in the long-short portfolio is given by $\omega_{i, t}$ and thus, the size of the positions depends on the strength of the signals. The long-short speculative pressure portfolio (hereafter, SP portfolio) thus formed is held for one month on a fully-collateralized basis $\left(\widetilde{\omega}_{i, t}=\omega_{i, t} / \sum_{i=1}^{N}\left|\omega_{i, t}\right|\right)$ which, by construction, implies that $50 \%$ of the investor's mandate is assigned to long (L) positions and 50\% to short (S) positions $\left(\sum_{i=1}^{N_{L}} \widetilde{\omega}_{i, t}^{L}=\sum_{i=1}^{N_{S}}\left|\widetilde{\omega}_{i, t}^{S}\right|=0.5\right)$. A new signal is obtained at month end $t+1$ to form another portfolio, and so forth until the end of the sample period.

The analysis is conducted, separately, for each of the four class-specific cross-sections of futures contracts, and also cross-class. For the latter purpose, the cross-class (or 'everywhere') SP portfolio return, $r_{S P, t+1}^{E}$, is defined as the weighted combination of the class-specific SP portfolio returns

$$
r_{S P, t+1}^{E}=\boldsymbol{\varphi}_{t}^{\prime} \boldsymbol{r}_{S P, t+1}=\sum_{c=1}^{4} \varphi_{t}^{c} r_{S P, t+1}^{c}
$$


where $\varphi_{t}^{c}, c=1, \ldots, 4$ are the class-allocation decisions based on past data, and $r_{S P, t+1}^{c}$ is the month $t$ to $t+1$ return of the SP portfolio for the $c$ th futures class. We employ the unconstrained meanvariance optimized weights $\boldsymbol{\varphi}_{t}=\frac{1}{\gamma} \boldsymbol{\Sigma}_{t}^{-1} \boldsymbol{\mu}_{t}$ where $\boldsymbol{\mu}_{t}$ is the $4 \times 1$ vector of mean excess returns for the class-specific SP portfolios and $\boldsymbol{\Sigma}_{t}$ is the corresponding $4 \times 4$ covariance matrix; both of which are estimated with data in the 60-month window preceding time $t$; the coefficient of relative risk aversion $\gamma$ is set to 5 . The allocations, $\boldsymbol{\varphi}_{t}$, are standardized so as to ensure full investment.

\subsection{Performance and Risk Analysis of Speculative Pressure Portfolios}

Figure 1 shows the evolution of $\$ 1$ invested in the class-specific (commodity, currency, equity index, fixed income) portfolios and the everywhere long-short SP portfolio. The plot is based on total returns (excess returns plus the 1-month U.S. Treasury bill rate) over the common period October 1998 to May 2018 (since a past window of 60-month excess returns per class-specific SP portfolio is used to optimize the class weights in the everywhere portfolio). The figure endorses the SP strategy in commodity, currency and equity index futures markets but not in the fixed income futures market. During the second half of the sample period the equity SP risk premium seems to be particular strong while the other SP risk premia have gradually weakened. The figure thus points towards the diversification benefits (in the form of stable returns) of an 'everywhere' SP portfolio.

[Insert Figure 1 around here]

The performance and risk of the long (L), short (S) and long-short (LS) portfolios based on speculative pressure are summarized in Table 2, Panel A. Over the period October 1993 to May 2018, the long-short SP portfolios obtain attractive annualized mean excess returns in commodity (4.12\%, $t$-statistic of 2.62), currency (2.51\%, $t$-statistic of 2.45$)$ and equity index (4.03\%, $t$-statistic of 2.29) futures markets. The SP risk premia are driven by both the outperformance of the 
backwardated contracts that we go long (ranging from $2.47 \%$ for commodity to $5.29 \%$ for equity index futures) and the underperformance of the contangoed contracts that we go short (ranging from $-5.77 \%$ for commodity to $-2.42 \%$ for currency futures). The reward-to-risk profile of the SP portfolios is also attractive as borne out, for instance, by annualized Sharpe ratios of $0.61,0.47$ and 0.50 or by positive certainty equivalent returns (CER) ${ }^{7}$ of $2.97 \%$ p.a., $1.74 \%$ p.a. and $2.39 \%$ p.a., respectively.

[Insert Table 2 around here]

These results confirm the extant wisdom of a speculative pressure premium in commodity futures markets and extend such knowledge to other futures markets such as currencies and equity indices. In contrast, no hedgers-to-speculators risk transfer is manifested in the fixed income futures market as borne out by a mean excess return of $-0.74 \%$ ( $t$-statistic of -1.49 ), a Sharpe ratio of -0.28 and a slightly negative CER at $-0.91 \% .{ }^{8}$ A potential reason may be that interest rate risk is hedged by temporarily changing the modified duration of the portfolios or by adopting immunization strategies. Alternatively, these findings could call for more unequivocal definitions of hedging versus speculation in fixed income futures markets and/or increased monitoring of the positions of participants, in particular as regards their declarations as hedgers or speculators.

${ }^{7}$ The power utility CER is given by $\left(\frac{12}{T}\right) \sum_{t=1}^{T} \frac{\left(1+r_{P, t}\right)^{1-\gamma}-1}{1-\gamma}$ with $r_{P, t}$ the month $t$ excess return of the portfolio. A positive CER implies that the portfolio is more attractive than the risk-free asset.

${ }^{8}$ Following Koijen et al. (2018), we adjust the fixed income and interest rate futures returns by the duration of the underlying security to ensure that the results are not duration-distorted. Thus, futures with higher (lower) durations are scaled down (up) in the long-short speculative pressure portfolio. The results are similar to those reported in Table 2 and thus we omit them to preserve space. 
Table 2, Panel B shows the correlation structure of the long-short SP portfolios per class of futures. It is interesting to note that the co-movement in their excess returns is mild ranging from $-1.5 \%$ to $16.9 \%$, at $5.5 \%$ on average. In line with Figure 1, these results suggest prima facie that the drivers of the SP risk premia may be class-specific rather than common across classes, and provide us with a motivation to construct an 'everywhere' SP portfolio based on unconstrained mean-variance optimized weights. As reported in the last column of Table 2, Panel A, the everywhere SP portfolio earns a statistically positive mean excess return ( $t$-statistic of 2.57) over the period October 1998 to May 2018. Its Sharpe ratio at 0.55 is higher than 0.33 , the average of the Sharpe ratios obtained for the class-specific SP portfolios over their common sample period. The incremental performance of the everywhere portfolio, alongside its very attractive crash risk profile, highlights the diversification benefits obtained when applying the SP strategy across futures classes.

\subsection{Do Speculators in Futures Markets Outperform Known Rule-Based Strategies?}

As benchmarks for our SP portfolios, we consider long-only class-specific portfolios that equally weight and monthly rebalance the futures contracts available within a given asset class of futures at the time of portfolio formation (AVG, hereafter), as well as an 'everywhere' AVG portfolio based on unconstrained mean-variance optimized weights for the class-specific AVG portfolios. Following the literature (Asness et al., 2013; Koijen et al., 2018), we also form long-short fullycollateralized momentum, value and carry portfolios within each asset class, and 'everywhere' portfolio counterparts based on unconstrained mean-variance optimized weights. The momentum signal is the average daily futures return over the previous year; namely, $x_{i, t} \equiv \frac{1}{D} \sum_{j=0}^{D-1} r_{i, t-j}$ where $D$ denotes the total number of days. The value signal is the difference between the log of the average of daily futures prices 4.5 to 5.5 years ago and the $\log$ of the futures price at month-end $t$; namely, $x_{i, t} \equiv \ln \left(\frac{1}{D} \sum_{d=4.5 y}^{5.5 y} f_{i, d}^{t_{1}}\right)-\ln \left(f_{i, t}^{t_{1}}\right)$ where $t_{1}$ is the maturity of the front-end contract. The carry 
signal is the month-end $t$ roll yield defined as the difference in the log prices of the front and second nearest contracts, $x_{i, t} \equiv \ln \left(f_{i, t}^{t_{1}}\right)-\ln \left(f_{i, t}^{t_{2}}\right)$ where $t_{1}$ and $t_{2}$ denote the contract maturities.

Figure 2 presents the Sharpe ratios of the different strategies per class and cross-class. It reveals that the magnitude of the SP premia in commodity, currency and equity index futures markets is similar to the momentum or carry premia and substantially exceeds that of the value and AVG premia. The fixed income class behaves differently from the other classes; we observe in fixed income futures markets the remarkable performance of the long-only AVG portfolio as highlighted by a Sharpe ratio at 0.54 and the poor performance of all the long-short strategies.

[Insert Figure 2 around here]

Appendix A reports detailed summary statistics for the excess returns of the AVG, momentum, value and carry portfolios which confirm that there is a significant momentum and carry effect in commodity and equity index futures markets (Jegadeesh and Titman, 1993; Miffre and Rallis, 2007; Asness et al., 2013; Koijen et al., 2018). The value strategy performs well in the context of currency futures but poorly elsewhere. Diversifying the risk of a given strategy across markets is beneficial for carry and AVG (t-statistics for the mean excess return of 4.11 and 1.98, respectively) but not necessarily for momentum and value ( $t$-statistics of 1.29 and 1.74 , respectively).

We then test whether speculators earn an additional return for their skills at picking up mispriced contracts over and above well-known strategies through the following time-series regression:

$$
r_{S P, t}=\alpha+\beta_{A V G} r_{A V G, t}+\beta_{M o m} r_{M o m, t}+\beta_{\text {Value }} r_{\text {Value }, t}+\beta_{\text {Carry }} r_{\text {Carry }, t}+\varepsilon_{t}
$$

where $r_{S P, t}$ is the month $t$ excess return of the long-short SP portfolio, and $r_{A V G, t}, r_{M o m, t}, r_{V a l u e, t}$ and $r_{\text {Carry, } t}$ are the month $t$ excess returns of the AVG, momentum, value and carry portfolios, 
respectively. Accordingly, the intercept measures the aforementioned additional returns. The OLS coefficient estimates and Newey-West robust $t$-statistics are presented in Table 3.

[Insert Table 3 around here]

The momentum coefficient, $\hat{\beta}_{M o m}$, is positive and strongly significant at the $1 \%$ level in commodity, currency and equity index futures markets. Our results confirm the extant wisdom that, pervasively across commodity, currency and equity index futures classes, speculators are positioned predominantly to benefit from trends, that is, they pursue momentum strategies (e.g., Moskowitz et al., 2012; Campbell \& Associates, 2013; Dewally et al., 2013; and Bhardwaj et al., 2014). The results confirm also that currency futures' speculators often trade on carry in line with extant findings (e.g., Fama, 1984; Menkhoff et al., 2012; Koijen et al., 2018). The insignificant intercept coefficient suggests that speculators in futures markets do not earn returns for special skills at detecting mispriced futures over and above the returns harnessed through publiclyavailable rule-based trading strategies such as momentum and carry. This result reaffirms a large and long-lasting literature that highlights the difficulty of active managers to outperform welldesigned benchmarks (Jensen, 1968; Malkiel, 1995; Dewally et al., 2013; Bhardwaj et al., 2014).

\subsection{Common Structure of Class-Specific Speculative Pressure Premia}

This section seeks to identify whether common risk factors drive the risk premia of the classspecific SP portfolios. To do this, we first extract the principal components of the four class-specific SP portfolio excess returns. As Table 4, Panel A shows, the first principal component merely explains $30.81 \%$ of the total variation. This result suggests that the excess returns of the SP portfolio do not represent compensation for exposure to a common underlying factor across futures classes. Further, the low explanatory power of the first principal component is also in line with the weak 
return correlations obtained across classes of futures (c.f., Table 2, Panel B). Both results point towards the lack of a common factor structure among the class-specific SP excess returns.

[Insert Table 4 around here]

Inspired by Asness et al. (2013) and Koijen et al. (2018), we complement this preliminary analysis by regressing the excess returns of the SP portfolios on business cycle variables, as well as shocks to global market liquidity, global funding liquidity and global volatility. ${ }^{9}$ The idea here is to test whether the performance of the SP portfolios drops during market downturns, when market liquidity suddenly dries out, when funding liquidity plunges and/or when global volatility unexpectedly rises. Such findings, consistent with rational pricing, would validate the hypothesis that the SP risk premia compensate investors for the drawdowns incurred in difficult times.

The business cycle variables are the changes in U.S. industrial production, default spread (calculated as the yield difference between Moody's seasoned Baa and Aaa corporate bonds), term spread (measured as the yield difference between 10-year Treasury constant maturity bond and 3month Treasury constant maturity bill), and the Kilian’s index of global real economic activity. In order to proxy for market liquidity, we first calculate at each month-end $t$ the Amivest liquidity ratio (Amihud et al., 1997) per futures contract, $L_{i, t}=\frac{1}{D} \sum_{d=1}^{D} \frac{\$ \text { Volume }_{i, d}}{\left|r_{i, d}\right|}$ (where $\$$ Volume $_{i, d}$ is the dollar daily volume of a given contract $i$ in day $d, D$ is the number of days in the two months prior to $t$ and $r_{i, d}$ is the day $d$ excess return of futures $i$ ). Then we equally weight the $L_{i, t}$ measure per futures $i$ within each class of futures and average the four class-specific liquidity measures to obtain

\footnotetext{
${ }^{9}$ The choice of risk factors is dictated by evidence that to some extent the momentum, value and carry premia relate to global recession, liquidity and volatility risks (Asness et al., 2013; Koijen et al., 2018). Since according to Section 3.3 speculators trade on momentum and carry, it is reasonable to hypothesize that the SP risk premia could likewise compensate investors for these risks.
} 
a global proxy for market liquidity. We proxy funding liquidity via the TED spread (measured as the difference between the 3-month U.S. LIBOR rate and the 3-month U.S. Treasury-bill rate). Finally, we proxy global volatility by first calculating the monthly realized variance (sum of the squared daily excess returns within a month) per futures contract and then the global volatility is the square root of the average of realized variances of futures within a class and finally across classes. Innovations or shocks to global market liquidity (denoted as $L_{t}$ hereafter), global funding liquidity $\left(T E D_{t}\right)$ and global volatility $\left(v_{t}\right)$ are defined as residuals from $\operatorname{AR}(2)$ models; similar unreported results are obtained with alternative AR(1) or AR(3) model specifications.

Table 4, Panel B, reports estimated coefficients and Newey-West adjusted t-statistics from contemporaneous regressions of the SP risk premia on the business cycle variables and the shocks to global liquidity and volatility risk factors. Practically, this amounts to replacing the independent variables of Equation (3) by the aforementioned measures. As the regressors are no longer tradeable factors, the intercept cannot be interpreted as a measure of abnormal performance. There is no evidence that the SP portfolios are exposed to business cycle variables nor to global market and funding liquidity shocks. The coefficient of global volatility is negative and statistically significant for the currency and equity index SP portfolios, and zero in statistical terms for the commodity and fixed income SP portfolios; thus, there is no pervasive evidence that the SP risk premia compensates investors for global volatility risk. Altogether these results suggest that the performance of the SP portfolios is not driven by known global risk factors. 


\section{Cross-Sectional Pricing}

This section tests whether the long-short SP portfolios price the cross-section of futures. Let $N$ denote the number of test assets. In the spirit of the Fama-MacBeth (1973) two-stage approach, we first measure the risk exposures of each test asset by OLS estimation of $N$ time-series regressions

$$
r_{i, t}=a_{i}+\boldsymbol{b}_{i} \boldsymbol{F}_{t}+\varepsilon_{i, t}
$$

where $r_{i, t}$ is the month $t$ excess return of test asset $i=1, \ldots, N, t=1, \ldots, T . \boldsymbol{F}_{t}$ is a vector of excess returns for the $K$ risk factors that can potentially price the cross-section and $\varepsilon_{i, t}$ are residuals. The OLS estimates, $\hat{a}_{i}$ and $\widehat{\boldsymbol{b}}_{i}{ }^{\prime}$ in Equation (4), are obtained over the full sample. At stage two, we obtain the prices of risk through sequential (monthly) cross-sectional OLS regressions

$$
r_{i, t}=\lambda_{0, t}+\lambda_{t} \widehat{\boldsymbol{b}}_{i}+\epsilon_{i, t}
$$

estimated at each month $t=1, \ldots, T$. We deploy a two-sided test for the significance of each risk price, $H_{0}: \bar{\lambda}_{j, t}=0$, using the Shanken (1992) corrected $t$-statistic with $\bar{\lambda}_{j, t}=\sum_{t=1}^{T} \hat{\lambda}_{j, t} / T$.

Three specifications are considered. The first baseline model just includes the excess returns of the long-short SP portfolio $\left(\boldsymbol{F}_{t}=\left\{r_{S P, t}\right\}\right)$. The second model augments the baseline specification with off-the-shelf tradeable risk factors emanating from the asset pricing literature $\left(\boldsymbol{F}_{t}=\right.$ $\left.\left\{r_{S P, t}, r_{A V G, t}, r_{\text {Mom }, t}, r_{\text {Value }, t}, r_{\text {Carry }, t}\right\}\right)$. The third model adds to the SP factor the non-tradeable factors - macroeconomic risks, shocks to global market liquidity, global funding liquidity and global volatility $\left(\boldsymbol{F}_{t}=\left\{r_{S P, t}, I P_{t}, D S_{t}, T E R M_{t}\right.\right.$, Kilian $\left.\left._{t}, L_{t}, T E D_{t}, v_{t}\right\}\right)$. The factor mimicking portfolios used as regressors are either class-specific (commodity, currency, equity index and fixed income futures portfolios) or cross-class ('everywhere' futures portfolios). The test assets are the 
$N=84$ futures contracts throughout to allow for the possibility that the speculative pressure factor in a given market influences the pricing of futures outside that market (de Roon et al., 2000).

[Insert Table 5 around here]

Table 5 presents estimates for $\bar{\lambda}_{0, t}$ and $\bar{\lambda}_{j, t}$, corresponding significance tests and adjusted- $R^{2}$ from Equation (5). It also reports the increase in explanatory power obtained when moving from a model that excludes the SP risk factor to a model that includes it $\left(\Delta \mathrm{adj}-R^{2}\right)$. The prices of SP risk are found to be positive and often statistically significant across models. On average, the price of SP risk equals $0.39 \%$ a month or $4.69 \%$ a year. Echoing our long-short portfolio results, this crosssectional pricing analysis reveals that the SP factors present in commodity, currency and equity index futures markets have significant information content. Also in line with the portfolio results, the evidence from these cross-sectional regressions suggests that fixed income futures markets behave differently as borne out by the weak pricing ability of their SP risk factor.

\section{Robustness Checks}

This section assesses our main findings in the light of alternative CFTC data, portfolio construction techniques, ranking/holding periods, transaction costs, illiquidity controls, and sub-periods.

\subsection{Alternative COT Reports}

We begin by considering alternative CFTC datasets. First, instead of the long and short positions of large speculators, we obtain from the Futures-Only COT report the weekly long $\left(L_{i, w}\right)$ and short $\left(S_{i, w}\right)$ positions of large commercial traders (also called hedgers) to measure for each contract a standardized hedging pressure signal $\omega_{i, t} \equiv\left(H P_{i, t}-\overline{H P}_{t}\right) / \sigma_{H P, t}$ where $H P_{i, t} \equiv \frac{1}{52} \sum_{w=1}^{52} \frac{S_{i, w}-L_{i, w}}{L_{i, w}+S_{i, w}}$. According to the hedging pressure hypothesis, backwardated futures with the most positive $\omega_{i, t}$ are expected to outperform contangoed futures with the most negative $\omega_{i, t}$. 
Second, we employ the Combined Futures and Options report of the CFTC which provides data on the long and short positions of large speculators in both futures and options markets; futures positions are synthetically replicated using portfolios of options.

Third, we also employ data from the Disaggregated COT report of the CFTC that splits the category of large speculators in commodity futures markets into two sub-categories: 1) 'managed money’ (CTAs, CPOs and hedge funds) and 2) 'other reportables’ (a wide array of mostly long non-commercial traders). Likewise, the Traders in Financial Futures (TFF) report splits the category of large speculators in financial futures markets into two sub-categories: 1) 'levered funds' and 2) 'asset manager/institutional'. The participants in the 'managed money' and 'levered funds' sub-categories take long and short positions in futures markets and, as such, they strictly qualify as speculators in the sense of Cootner (1960)'s theory; ${ }^{10}$ accordingly, we refine our analysis by measuring the SP signal, Equation (1) using data on these two types of traders only.

Table 6 summarizes the outcome of this analysis. Panel A summarizes the alternative SP portfolios, and reports the intercept $(\alpha)$ and slope coefficient $(\beta)$ from a time-series regression of the excess returns of a given alternative SP portfolio on the excess returns of the corresponding baseline SP portfolio (as obtained in our main analysis). We test for the potential superiority of the refined SP premium over the baseline SP premium $(\alpha>0)$. Panel B focuses on the ability of the alternative SP risk factors to price cross-sectionally the $N=84$ futures contracts after controlling for the corresponding AVG, momentum, value and carry risk factors. The starting dates for the classspecific portfolios depend on data availability: October 1993 for the Futures-Only COT report,

\footnotetext{
10 The participants in the 'other reportables' and 'asset manager/institutional' sub-categories do not qualify as pure speculators in Cootner (1960) sense as they merely seek naïve long-only strategic exposure to a given asset class.
} 
March 1996 for the Combined Futures and Options COT report, and June 2007 for the Disaggregated COT and TFF reports. The 'everywhere’ portfolios always start 5 years later by construction (class weights optimization). All the portfolios end in May 2018.

\section{[Insert Table 6 around here]}

The results confirm the main findings. Trading on the alternative signals generates significant mean excess returns in commodity and equity index futures markets, in an everywhere context and, to a lower extent, in currency futures markets. There is no SP premia in fixed income futures markets. With only four exceptions, the null hypothesis $\alpha=0$ is not rejected at conventional significance levels and thus, generally speaking, the portfolios based on the alternative signals perform similarly as those discussed in our main analysis (Section 3). The cross-sectional pricing results are also analogous, in terms of both statistical and economic relevance, as those discussed earlier.

\subsection{Alternative Portfolio Construction Methods}

Thus far, we have modeled the SP risk premium using the entire cross-section of futures available at each portfolio formation time with weights given by the standardized signals; namely, $\omega_{i, t} \equiv$ $\left(S P_{i, t}-\overline{S P}_{t}\right) / \sigma_{S P, t}$. We now test, first, the robustness of our conclusions to portfolios based on the extreme terciles. Second, we deploy other weighting schemes on the entire cross-section of futures. The first scheme is based on equal weights, going long $\left(\omega_{i, t}^{L} \equiv+1\right)$ the $50 \%$ of the cross-section with highest $S P_{i, t}$ in Equation (1) and short $\left(\omega_{i, t}^{S} \equiv-1\right)$ the remaining 50\%. The second scheme is based on the standardized ranks; namely, $\omega_{i, t} \equiv\left(z_{i, t}-\bar{z}_{t}\right) / \sigma_{Z, t}$ where $z_{i, t} \in\{1, \ldots, N\}$ is the $i$ th asset rank at time $t$ based on the SP signal as obtained from Equation (1), $\bar{z}_{t}$ and $\sigma_{Z, t}$ are the time $t$ cross-sectional mean and standard deviation of $z_{i, t}$. The third weighting scheme, inspired by risk parity (Moskowitz et al., 2012; Asness et al., 2013), allocates more (less) weights to assets with 
lower (higher) volatilities. ${ }^{11}$ In all settings, the long and short positions are fully collateralized with equal mandates allocated to the long and short portfolios, as previously. Table 7 shows the results.

[Insert Table 7 around here]

The portfolio results in Table 7, Panel A, are broadly consistent with those obtained thus far; the SP risk premia are significantly positive in commodity, currency and equity index futures markets but not in fixed income futures markets. The time-series regression results also suggest that the alternative portfolio formation methods do not add value to those employed in our main analysis. The cross-sectional results, while weaker for the equal-weight scheme, confirm the presence of a positive price of SP risk in commodity, currency, and equity index futures markets. ${ }^{12}$

\subsection{Alternative Ranking and Holding Periods}

Thus far we have used a lookback (ranking) period of 12 months for the SP signals, and the longshort portfolios thus formed were held for one month. Figure 3 tests the sensitivity of the Sharpe ratios to the choice of ranking and holding periods. Panel A allows for various ranking periods, while adhering to the one month holding period. Panel B allows for various holding periods, while fixing the ranking period to 12 months. In order to provide comparable results, both panels are based on the common sample from October 1994 to May 2018 for the asset-class specific portfolios (October 1999 to May 2018 for the everywhere portfolios). The general picture remains unchanged.

${ }^{11}$ The allocations are given by the risk-adjusted speculative pressure $\widetilde{S P}_{i, t} \equiv S P_{i, t} \sigma_{i, t}^{-1}$, with $\sigma_{i, t}$ the standard deviation of the daily excess returns of the $i$ th futures contract in the preceding year. As previously, we use the standardized signal $\omega_{i, t} \equiv\left(\widetilde{S P}_{i, t}-\widetilde{S P}_{t}\right) / \sigma_{\widetilde{P P}, t}$.

${ }^{12}$ In these cross-sectional regressions, in place of the momentum, value and carry portfolios based on the full cross-section and standardized signals, for consistency we use as independent variables variants thereof based on terciles, equal weights, standardized ranking, and risk-parity weights. 
However, higher Sharpe ratios are obtained with shorter ranking periods in equity index futures markets and over longer ranking periods in commodity and currency futures markets.

[Insert Figure 3 around here]

\subsection{Transaction Costs}

To get a sense of how trading intensive the speculative pressure strategy is, we measure the portfolio turnover (TO) defined as the time average of all the trades incurred:

$$
T O=\frac{1}{T-1} \sum_{t=1}^{T-1} \sum_{i=1}^{N}\left(\left|\widetilde{\omega}_{i, t+1}-\widetilde{\omega}_{i, t^{+}}\right|\right)
$$

where $t=1, \ldots, T$ denotes each of the (month-end) portfolio formation periods in the sample, $\widetilde{\omega}_{i, t}$ is the weight assigned to the $i$ th futures contract at month $t$ as dictated by the SP strategy, $\widetilde{\omega}_{i, t^{+}} \equiv$ $\widetilde{\omega}_{i, t} \times e^{r_{i, t+1}}$ is the actual portfolio weight right before the next rebalancing at $t+1$, and $r_{i, t+1}$ is the monthly return of the $i$ th futures from month-end $t$ to month-end $t+1$. Thus, TO captures the mechanical evolution of the weights due to within-month price dynamics.

We also calculate the excess return of the long-short portfolio $P$ net of transaction costs $T C$

$$
\tilde{r}_{P, t+1}=\sum_{i=1}^{N} \widetilde{\omega}_{i, t} r_{i, t+1}-T C \sum_{i=1}^{N}\left|\widetilde{\omega}_{i, t}-\widetilde{\omega}_{i, t-1^{+}}\right|
$$

and calculate the breakeven round-trip proportional trading cost required to make $\tilde{r}_{P, t+1}=0$.

The results are reported in Table 8. Interestingly, with an average monthly turnover of 0.16 , the SP strategy is far less trading intensive than the momentum or carry strategies with an average turnover of 0.37 and 0.47 , respectively. The required proportional transaction costs that make the SP portfolio unprofitable are remarkably high in commodity, currency and equity index futures markets and cross-market as well (at 1.66\% on average). This breakeven transaction costs compare favorably to those obtained for the momentum (1.24\%), value (0.70\%) or carry $(1.47 \%)$ strategies 
and to the round-trip transaction costs reported in the futures pricing literature $(0.086 \%$ according to Marshall et al., 2012). Thus, we can conclude that net of reasonable transaction costs, the SP strategy delivers appealing Sharpe ratios in commodity, currency and equity index futures markets.

[Insert Table 8 around here]

\subsection{Liquidity Considerations}

Thus far, we have included in the analysis any futures contract with open interest data available on non-commercial participants at the time of portfolio formation. This could create liquidity distortions which we circumvent now by focusing on a restricted cross-section that excludes the $10 \%$ or $20 \%$ least liquid futures contracts (namely, the decile or quintile with lowest open interest at the time of portfolio formation month $t$ ). Summary statistics for the resulting SP premia are presented in Table 9 and to ease comparison, we reproduce the risk premia obtained with the whole cross-section of contracts from Table 2. Differences in performance are negligible which suggests that the risk premia identified in our main analysis do not reflect compensation for liquidity risk.

[Insert Table 9 around here]

\subsection{Sub-Period Analysis}

Finally, we test the robustness of our key findings to the choice of timeframe by measuring the Sharpe ratios of the SP portfolios over various sub-periods: $i$ ) high versus low volatility regimes, ${ }^{13}$ ii) recession versus expansion months according to the NBER business cycle dating, iii) the Dodd-

13 The volatility regimes per class or 'everywhere' (cross-class) are obtained by fitting a GARCH(1,1) model to the corresponding AVG excess returns. The means of the fitted annualized volatilities, used as cut-off points, equal $12.21 \%$ for commodities, $8.03 \%$ for currencies, $14.40 \%$ for equity indices, 3.53\% for fixed income securities, and 3.12\% for the everywhere portfolio. 
Frank Wall Street Reform dated July $2010^{14}$, iv) the U.S. Quantitative Easing (QE) from December 2008 onwards, and v) non-overlapping 5-year rolling periods. Table 10 reports the results.

[Insert Table 10 around here]

While the main findings are unchallenged, the results as regards to which sub-periods provide the best SP premia are not consistent across futures classes. For example, the SP premia are larger during expansions than recessions in currency and equity index futures markets but this pattern is reversed in commodity futures markets. Likewise, the SP strategy performs better post-QE than pre-QE period in commodity and equity index futures markets, and the other way around in currency futures markets. This cross-class heterogeneity reinforces our previous finding that the observed SP risk premia are not driven by a common factor structure, and ensures diversification as borne out by the superior Sharpe ratios of the 'everywhere' SP portfolio in all (but one) of the sub-periods.

\section{Conclusions}

Using data from September 30, 1992 to May 25, 2018 on a broad cross-section of 84 futures instruments pertaining to four asset classes this article investigates the price formation role of speculative pressure (net positions of speculators). First, we assess the extent to which long-short speculative pressure portfolios capture a premium in commodity, currency, equity index and fixed income futures markets. Second, we test whether the thus formed futures-class specific and ‘everywhere’ speculative pressure factors can price the broad cross-section of futures returns.

\footnotetext{
${ }^{14}$ One of the main regulatory arrangements of the Dodd-Frank Wall Street Reform and Consumer Protection Act was to authorize the U.S. CFTC to establish higher margin requirements to protect the financial integrity of futures markets.
} 
Long-short portfolios based on speculative pressure as sorting signal are able to generate economically sizeable and statistically significant mean excess returns in commodity (at 4.12\% p.a.), currency (2.51\% p.a.) and equity index futures markets (4.03\% p.a.). Speculative pressure factors constructed from commodity, currency and equity index futures data are able to explain the broad cross-section of futures returns after accounting for momentum, value and carry factors or for macroeconomic, liquidity and volatility risk factors. These key findings withstand a battery of robustness tests based on alternative Commitments of Traders reports data, alternative portfolio construction techniques, holding and ranking periods, sub-periods, and controlling for transaction costs and illiquidity. The main finding - well-functioning futures markets that efficiently transfer the price risk from hedgers to speculators - is reassuring from a regulatory perspective.

By contrast, the above finding does not extend to fixed income futures markets. This could be interpreted as a sign that a more unequivocal conceptualization of the hedging versus speculation trading motives and/or increased monitoring of the positions of market participants as regards their declarations are warranted in these specific markets. We hope that our findings will instigate further research on both regulation and factor investing in fixed income futures markets. 
Appendix A. Traditional risk premia

The appendix presents summary statistics for the excess returns of traditional benchmarks. AVG is a long-only equally-weighted portfolio of the constituents of a given market. Momentum, Value and Carry are long-short portfolios based on the corresponding signals. The results are presented per class of futures (commodity, currency, equity index and fixed income) and across classes (everywhere). Mean and StDev have been annualized. Newey-West h.a.c. robust $t$-statistics are reported in parentheses for the mean excess returns. Sharpe ratio is measured as Mean divided by StDev, Sortino ratio is calculated as Mean divided by annualized downside deviation and Omega ratio is measured as the probability weighted ratio of gains versus losses (the latter two ratios use $0 \%$ as threshold). CER is the certainty equivalent return that an investor with power utility preferences is willing to accept instead of engaging in the SP strategy. The sample period is October 1993 to May 2018 for the class-specific futures portfolios and October 1998 to May 2018 for the 'everywhere' futures portfolios.

\begin{tabular}{|c|c|c|c|c|c|c|c|c|c|c|c|c|c|c|c|c|c|c|c|c|}
\hline & \multicolumn{5}{|c|}{ AVG } & \multicolumn{5}{|c|}{ Momentum } & \multicolumn{5}{|c|}{ Value } & \multicolumn{5}{|c|}{ Carry } \\
\hline & Comm. & Currency & $\begin{array}{l}\text { Equity } \\
\text { index }\end{array}$ & $\begin{array}{c}\text { Fixed } \\
\text { income }\end{array}$ & $\begin{array}{l}\text { Every- } \\
\text { where }\end{array}$ & Comm. & Currency & $\begin{array}{l}\text { Equity } \\
\text { index }\end{array}$ & $\begin{array}{c}\text { Fixed } \\
\text { income }\end{array}$ & $\begin{array}{l}\text { Every- } \\
\text { where }\end{array}$ & Comm. & Currency & $\begin{array}{l}\text { Equity } \\
\text { index }\end{array}$ & $\begin{array}{c}\text { Fixed } \\
\text { income }\end{array}$ & $\begin{array}{l}\text { Every- } \\
\text { where }\end{array}$ & Comm. & Currency & $\begin{array}{l}\text { Equity } \\
\text { index }\end{array}$ & $\begin{array}{c}\text { Fixed } \\
\text { income }\end{array}$ & $\begin{array}{l}\text { Every- } \\
\text { where }\end{array}$ \\
\hline hean & $\begin{array}{r}-0.0079 \\
(-0.27)\end{array}$ & $\begin{array}{r}0.0144 \\
(0.81)\end{array}$ & $\begin{array}{r}0.0273 \\
(0.90)\end{array}$ & $\begin{array}{r}0.0192 \\
(2.60)\end{array}$ & $\begin{array}{r}0.0162 \\
(1.98)\end{array}$ & $\begin{array}{r}0.0468 \\
(2.59)\end{array}$ & $\begin{array}{r}0.0075 \\
(0.46)\end{array}$ & $\begin{array}{r}0.1387 \\
(2.83)\end{array}$ & $\begin{array}{r}0.0009 \\
(0.13)\end{array}$ & $\begin{array}{r}0.0163 \\
(1.29)\end{array}$ & $\begin{array}{r}0.0238 \\
(1.19)\end{array}$ & $\begin{array}{rr}3 & 0.0295 \\
) & (2.69)\end{array}$ & $\begin{array}{r}-0.0258 \\
(-0.74)\end{array}$ & $\begin{array}{r}0.0008 \\
(0.11)\end{array}$ & $\begin{array}{r}0.0144 \\
(1.74)\end{array}$ & $\begin{array}{r}0.0479 \\
(2.06)\end{array}$ & $\begin{array}{r}0.0378 \\
(1.64)\end{array}$ & $\begin{array}{r}0.1658 \\
(3.12)\end{array}$ & $\begin{array}{r}0.0082 \\
(1.16)\end{array}$ & $\begin{array}{r}0.0385 \\
(4.11)\end{array}$ \\
\hline Dev & 0.1207 & 0.0794 & 0.1393 & 0.0353 & 0.0387 & 0.0946 & 0.0638 & 0.2116 & 0.0361 & 0.0525 & 0.0979 & 0.0505 & 0.1450 & 0.0341 & 0.0375 & 0.1095 & 0.1015 & 0.2376 & 0.0330 & 0.0407 \\
\hline tewness & $\begin{array}{r}-0.7241 \\
(-5.09)\end{array}$ & $\begin{array}{r}-0.5297 \\
(-3.72)\end{array}$ & $\begin{array}{r}-0.8300 \\
(-5.83)\end{array}$ & $\begin{array}{r}-0.0641 \\
(-0.45)\end{array}$ & & $\begin{array}{r}0.0998 \\
(0.70)\end{array}$ & $\begin{array}{r}-0.8210 \\
(-5.77)\end{array}$ & & & & $\begin{array}{r}-0.0722 \\
(-0.51)\end{array}$ & $\begin{array}{r}-0.0380 \\
(-0.27)\end{array}$ & & $\begin{array}{r}-0.1123 \\
(-0.79)\end{array}$ & & $\begin{array}{r}0.3932 \\
(2.76)\end{array}$ & $\begin{array}{l}1.8025 \\
(12.66)\end{array}$ & $\begin{array}{r}0.4203 \\
(2.95)\end{array}$ & $\begin{array}{r}-0.1618 \\
(-1.14)\end{array}$ & $\begin{array}{r}-0.2968 \\
(-1.86)\end{array}$ \\
\hline xcess kurtosis & & $\begin{array}{r}2.6712 \\
(9.38)\end{array}$ & & $\begin{array}{r}1.3122 \\
(4.61)\end{array}$ & & & & & & & & $\begin{array}{r}2.6499 \\
(9.31)\end{array}$ & & & & $\begin{array}{r}1.7036 \\
(5.98)\end{array}$ & $\begin{array}{l}44.4139 \\
(155.98)\end{array}$ & & $\begin{array}{r}1.5192 \\
(5.34)\end{array}$ & $\begin{array}{r}1.6953 \\
(5.32)\end{array}$ \\
\hline$\%$ & 0.1237 & 0.0729 & 0.1252 & 0.0257 & 0.0290 & 0.0577 & 0.0608 & 0.1870 & 0.0277 & 0.0398 & 0.0669 & 0.0409 & 0.1690 & 0.0257 & 0.0347 & 0.0712 & 0.2947 & 0.2162 & 0.0259 & 0.0310 \\
\hline of $p$ & 5338 & 5541 & 5642 & 0.5473 & 508 & 5507 & 0.5439 & 0.5980 & 0.5203 & 5847 & 0.5169 & 0.6014 & 0.4493 & 0.5034 & 0.5636 & 0.5405 & 0.6014 & 0.5912 & 0.5372 & 0.6483 \\
\hline laxin & -0.4874 & -0.3164 & -0.6007 & -0.0720 & -0.1 & -0.2215 & -0.3517 & -0.4336 & -0.1460 & -0.1 & -0.3271 & -0.0952 & -0.7236 & -0.1914 & -0.0800 & -0.2571 & -0.2966 & -0.4854 & -0.0917 & -0.0753 \\
\hline & & & & & & & & & & & & & & & & & & & & \\
\hline rtin & -0.0835 & 392 & 408 & 0.8678 & & 3745 & 1437 & 3601 & 0370 & & 3917 & 0.8348 & -0.2368 & 0.0349 & & 0.7348 & 0.4339 & 0.9878 & 0.3627 & 1.4073 \\
\hline neg & 0.9489 & & 1.1665 & 1.5044 & & 1.4339 & 1.0978 & .7117 & & & 1.1956 & 1.5998 & 0.8539 & 1.0168 & & 1.4094 & 1.4930 & 1.8365 & 1.2089 & 2.0127 \\
\hline & -0.0474 & -0.0018 & -0.0254 & 0.0161 & 0.0124 & 0.0245 & -0.0030 & 0.0173 & -0.0024 & 0.0093 & -0.0002 & 0.0230 & -0.0843 & -0.0021 & 0.0109 & 0.0185 & 0.0119 & 0.0196 & 0.0054 & 0.0342 \\
\hline
\end{tabular}




\section{References}

Amihud, Y., Mendelson, H., \& Lauterbach, B. (1997). Market microstructure and securities values: Evidence from the Tel Aviv Stock Exchange. Journal of Financial Economics, 45, 365-390.

Anderson, R., \& Danthine, J.-P. (1983). Hedger diversity in futures markets. Economic Journal, 93, 370-389.

Asness, C., Moskowitz, T., \& Pedersen, L. (2013). Value and momentum everywhere. Journal of Finance, 68, 929-985.

Basu, D. \& Miffre, J. (2013). Capturing the risk premium of commodity futures: The role of hedging pressure. Journal of Banking and Finance, 37, 2652-2664.

Bessembinder, H. (1992). Systematic risk, hedging pressure, and risk premiums in futures markets. Review of Financial Studies, 5, 637-667.

Bhardwaj, G., Gorton, G., \& Rouwenhorst, K. G. (2014). Fooling some of the people all of the time: The inefficient performance of commodity trading advisors. Review of Financial Studies, 27, 3099-3132.

Campbell \& Company (2013). Prospects for CTAs in a rising interest rates environment. Campbell White Paper Series January 2013.

Chang, E. (1985). Return to speculators and the theory of normal backwardation. Journal of Finance, 40, 193-208.

Cootner, P. (1960) Returns to speculators: Telser vs. Keynes, Journal of Political Economy, 68, 396-404.

Cootner, P. (1967). Speculation and hedging. Food Research Institute Studies, 7, 65-103.

Daskalaki, C., Kostakis, A., \& Skiadopoulos, G. (2014). Are there common factors in individual commodity futures returns? Journal of Banking and Finance, 40, 346-363.

de Roon, F. A., Nijman, T. E., \& Veld, C. (2000). Hedging pressure effects in futures markets. Journal of Finance, 55, 1437-1456.

Dewally, M., Ederington, L., \& Fernando, C. (2013). Determinants of trader profits in commodity futures markets. Review of Financial Studies, 26, 2648-2683.

Ederington, L., \& Lee J. H. (2002). Who trades futures and how: Evidence from the heating oil futures market. Journal of Business, 75, 353-373.

Fama, E. F. (1984). Forward and spot exchange rates. Journal of Monetary Economics, 14, 319338.

Fama, E. F. \& MacBeth, J. D. (1973). Risk, returns, and equilibrium: Empirical tests. Journal of Political Economy, 81, 607-636. 
Fattouh, B., Kilian, L., \& Mahadeva, L. (2013). The role of speculation in oil markets: What have we learned so far?, Energy Journal 34, 7-33

Gorton, G., Hayashi, F., \& Rouwenhorst, G. (2013). The fundamentals of commodity futures returns. Review of Finance, 17, 35-105.

Hicks, J. R. (1939). Value and Capital. Oxford University Press, Cambridge, U.K.

Hirshleifer, D. (1988). Residual risk, trading costs, and commodity futures risk premia. Review of Financial Studies, 1, 173-193.

Hirshleifer, D. (1989). Determinants of hedging and risk premia in commodity futures markets. Journal of Financial and Quantitative Analysis, 24, 313-331.

Irwin, S., Sanders, D. \& Merrin R. (2009). Devil or angel? The role of speculation in the recent commodity price boom (and bust), Journal of Agricultural and Applied Economics, 377-391.

Jensen, M., (1968). The performance of mutual funds in the period 1945-1964. Journal of Finance, 23, 389-416.

Jegadeesh, N. \& Titman, S. (1993). Returns to buying winners and selling losers: Implications for stock market efficiency. Journal of Finance, 48, 65-91.

Kang, W., Rouwenhorst, G., \& Tang, K. (2019). A tale of two premiums: The role of hedgers and speculators in commodity futures markets. Journal of Finance, forthcoming.

Keynes, M. (1930). A Treatise on Money II: The Applied Theory of Money. Edition, Macmillan and Co., U.K.

Koijen, R., Moskowitz, T., Pedersen, L., \& Vrugt, E. (2018). Carry. Journal of Financial Economics, 127, 197-225.

Malkiel, B., (1995). Returns from investing in equity mutual funds 1971 to 1991. Journal of Finance, 50, 549-572.

Marshall, B. R., Nguyen, N. H., \& Visaltanachoti, N. (2012). Commodity liquidity measurement and transaction costs. Review of Financial Studies, 25, 599-638.

Menkhoff, L., Sarno, L., Schmeling, M., \& Schrimpf, A. (2012). Currency momentum strategies. Journal of Financial Economics, 106, 620-684.

Miffre, J. \& Rallis, G. (2007). Momentum strategies in commodity futures markets. Journal of Banking and Finance, 31, 1863-1886.

Moskowitz, T. J., Ooi, Y.-H., \& Pedersen, L. H. (2012). Time series momentum. Journal of Financial Economics, 104, 228-250.

Rouwenhorst. K. G. \& Tang, K. (2012). Commodity investing. Annual Review of Financial Economics, 4, 447-467. 
Shanken, J. (1992). On the estimation of beta-pricing models. Review of Financial Studies, 5, 133.

Stoll, H., \& Whaley, R. (2010). Commodity index investing and commodity futures prices. Journal of Applied Finance, 20, 7-46.

Stulz, R. (1984). Optimal hedging policies. Journal of Financial and Quantitative Analysis, 19, 127-140.

Szymanowska, M., de Roon, F., Nijman, T., \& Van Den Goorbergh, R. (2014). An anatomy of commodity futures risk premia. Journal of Finance, 69, 453-482. 


\section{Table 1. Overview of futures contracts}

The table reports for 84 futures contracts the annualized mean and standard deviation of excess returns, as well as the mean and standard deviation of the speculative pressure characteristic, Equation (1), based on the prior year speculators' positions. $\% S P>0$ is the percentage of months when speculative pressure is positive (speculators are net long). The sample period is September 1992 to May 2018.

\begin{tabular}{|c|c|c|c|c|c|c|c|c|c|c|c|}
\hline & \multicolumn{2}{|c|}{ Excess return } & \multicolumn{3}{|c|}{ Speculative pressure } & & \multicolumn{2}{|c|}{ Excess return } & \multicolumn{3}{|c|}{ Speculative pressure } \\
\hline & Mean & StDev & Mean & StDev & $\% S P>0$ & & Mean & StDev & Mean & StDev & $\% S P>0$ \\
\hline \multicolumn{6}{|c|}{ Panel A: Commodities ( $\mathrm{N}=43$ ) } & \multicolumn{6}{|c|}{ Panel B: Currencies ( $\mathrm{N}=11)$} \\
\hline BFP milk & 0.00 & 0.25 & 0.03 & 0.37 & 54.77 & African rand & 0.02 & 0.16 & 0.45 & 0.11 & 100.00 \\
\hline Brent crude oil & -0.05 & 0.32 & -0.40 & 0.22 & 1.41 & Australian dollar & 0.02 & 0.12 & 0.24 & 0.43 & 72.03 \\
\hline Butter cash & 0.00 & 0.23 & -0.02 & 0.11 & 50.00 & Brazilian real & 0.04 & 0.19 & 0.19 & 0.40 & 76.42 \\
\hline Cheese cash & 0.01 & 0.19 & -0.59 & 0.17 & 0.00 & Canadian dollar & 0.00 & 0.08 & 0.08 & 0.35 & 56.57 \\
\hline Coal & -0.09 & 0.25 & 0.72 & 0.10 & 100.00 & Euro & 0.00 & 0.10 & 0.08 & 0.38 & 55.95 \\
\hline Cocoa & 0.01 & 0.30 & 0.18 & 0.31 & 71.04 & Japanese yen & -0.03 & 0.11 & -0.21 & 0.35 & 34.68 \\
\hline Coffee C & -0.04 & 0.36 & 0.19 & 0.24 & 75.08 & Mexican peso & 0.03 & 0.12 & 0.31 & 0.36 & 81.18 \\
\hline Corn & -0.07 & 0.27 & 0.27 & 0.24 & 90.24 & New Zealand dollar & 0.02 & 0.13 & 0.35 & 0.28 & 82.07 \\
\hline Cotton number 2 & -0.02 & 0.28 & 0.10 & 0.32 & 66.67 & Russian ruble & 0.05 & 0.25 & 0.41 & 0.33 & 90.20 \\
\hline Electricity JPM & -0.16 & 0.49 & 0.48 & 0.30 & 92.09 & Sterling & 0.00 & 0.08 & -0.05 & 0.30 & 39.39 \\
\hline Ethanol & 0.30 & 0.36 & 0.44 & 0.20 & 96.91 & Swiss franc & 0.00 & 0.11 & -0.15 & 0.28 & 30.07 \\
\hline Feeder cattle & 0.01 & 0.15 & 0.23 & 0.16 & 90.24 & & & & & & \\
\hline Frozen orange juice & -0.05 & 0.30 & 0.28 & 0.27 & 79.46 & \multicolumn{6}{|c|}{ Panel C: Equity indices ( $N=19$ ) } \\
\hline Frozen pork bellies & 0.02 & 0.37 & 0.02 & 0.18 & 54.73 & DJIA & 0.04 & 0.15 & -0.05 & 0.27 & 50.35 \\
\hline Gold 100 oz (CMX) & 0.02 & 0.16 & 0.27 & 0.41 & 75.08 & E-mini MSCI EAFE & 0.02 & 0.18 & 0.40 & 0.35 & 86.44 \\
\hline Gold 100 oz (NYL) & 0.06 & 0.18 & 0.27 & 0.03 & 100.00 & E-mini $\mathrm{MSCl}$ emerging & 0.00 & 0.24 & 0.39 & 0.21 & 94.90 \\
\hline Heating oil & 0.04 & 0.30 & 0.15 & 0.22 & 74.75 & E-mini NASDAQ 100 & 0.04 & 0.25 & 0.18 & 0.24 & 70.27 \\
\hline High grade copper & 0.05 & 0.26 & 0.09 & 0.26 & 57.24 & E-mini Russell 2000 & 0.08 & 0.18 & -0.23 & 0.26 & 25.14 \\
\hline HR coil steel & -0.02 & 0.20 & -0.22 & 0.09 & 0.00 & E-mini S\&P 400 midcap & 0.08 & 0.16 & 0.23 & 0.36 & 80.11 \\
\hline Lean hogs & -0.07 & 0.28 & 0.18 & 0.19 & 80.47 & Eurotop 100 & 0.06 & 0.17 & 0.41 & 0.48 & 74.51 \\
\hline Light crude oil & 0.03 & 0.32 & 0.20 & 0.23 & 82.15 & Major market index & 0.16 & 0.13 & 0.16 & 0.39 & 72.32 \\
\hline Live cattle & -0.01 & 0.15 & 0.25 & 0.16 & 94.28 & Maxi value line & 0.09 & 0.14 & -0.48 & 0.26 & 0.00 \\
\hline Lumber & -0.10 & 0.31 & 0.09 & 0.21 & 62.84 & Mini Dow Jones & 0.08 & 0.13 & 0.19 & 0.29 & 75.81 \\
\hline Mini soyabeans & 0.09 & 0.28 & 0.68 & 0.14 & 100.00 & Mini S\&P 500 & 0.04 & 0.15 & -0.01 & 0.15 & 43.57 \\
\hline Natural gas & -0.22 & 0.48 & -0.10 & 0.28 & 27.61 & NASDAQ 100 & 0.08 & 0.27 & -0.06 & 0.22 & 35.87 \\
\hline NY unleaded gas & 0.15 & 0.33 & 0.38 & 0.25 & 89.31 & Nikkei 225 & -0.01 & 0.21 & 0.08 & 0.27 & 71.04 \\
\hline Oats & -0.01 & 0.32 & 0.42 & 0.22 & 94.28 & NYSE composite & 0.05 & 0.14 & 0.19 & 0.14 & 100.00 \\
\hline Palladium & 0.07 & 0.34 & 0.46 & 0.33 & 87.96 & PSE technology & 0.18 & 0.33 & 0.39 & 0.12 & 100.00 \\
\hline Platinum & 0.04 & 0.22 & 0.57 & 0.17 & 100.00 & Russell 2000 & 0.04 & 0.18 & -0.05 & 0.40 & 48.04 \\
\hline RBOB gasoline & 0.00 & 0.32 & 0.53 & 0.14 & 100.00 & S\&P 400 midcap & 0.08 & 0.17 & 0.23 & 0.44 & 65.43 \\
\hline Rough rice & -0.10 & 0.27 & 0.05 & 0.37 & 52.53 & S\&P 500 & 0.06 & 0.15 & -0.07 & 0.30 & 37.37 \\
\hline Silver 1000 oz & -0.11 & 0.24 & -0.48 & 0.19 & 0.00 & VIX & -0.58 & 0.53 & -0.16 & 0.28 & 11.81 \\
\hline Silver 500 oz & 0.02 & 0.29 & 0.51 & 0.18 & 100.00 & & & & & & \\
\hline Soyabean meal & 0.12 & 0.28 & 0.33 & 0.26 & 86.53 & \multicolumn{6}{|c|}{ Panel D: Fixed Income ( $\mathrm{N}=11$ ) } \\
\hline Soyabean oil & -0.04 & 0.25 & 0.22 & 0.27 & 82.15 & 1-month Eurodollar & 0.00 & 0.01 & 0.21 & 0.32 & 65.00 \\
\hline Soyabeans & 0.05 & 0.25 & 0.29 & 0.26 & 83.16 & 30-day FED funds & 0.00 & 0.01 & 0.15 & 0.38 & 63.64 \\
\hline Sugar number 11 & -0.01 & 0.30 & 0.32 & 0.27 & 87.88 & 30-year U.S. T-bond & 0.04 & 0.09 & 0.04 & 0.28 & 48.48 \\
\hline Sugar number 14 & 0.00 & 0.11 & -0.77 & 0.00 & 0.00 & 3-month Eurodollar & 0.00 & 0.01 & 0.11 & 0.38 & 56.57 \\
\hline Wheat (CBT) & -0.12 & 0.29 & 0.03 & 0.20 & 46.13 & 90-day U.S. T-bill & 0.01 & 0.01 & 0.16 & 0.23 & 84.06 \\
\hline Wheat (KCBT) & -0.01 & 0.29 & 0.29 & 0.27 & 84.18 & 2-year U.S. T-note & 0.01 & 0.02 & 0.04 & 0.18 & 62.29 \\
\hline Wheat (MGE) & 0.03 & 0.28 & 0.23 & 0.40 & 66.89 & 5-year U.S. T-note & 0.02 & 0.04 & 0.05 & 0.21 & 52.53 \\
\hline White wheat & -0.09 & 0.26 & 0.74 & 0.31 & 100.00 & 10-year agency note & 0.08 & 0.08 & -0.33 & 0.18 & 0.00 \\
\hline \multirow[t]{3}{*}{ WTI crude oil } & -0.12 & 0.31 & 0.26 & 0.15 & 100.00 & 10-year U.S. T-note & 0.03 & 0.06 & 0.00 & 0.19 & 46.80 \\
\hline & & & & & & Municipal bond index & 0.04 & 0.07 & 0.21 & 0.33 & 63.10 \\
\hline & & & & & & Ultra T-bond composite & 0.06 & 0.12 & -0.18 & 0.23 & 26.60 \\
\hline
\end{tabular}


Table 2. Speculative pressure risk premia: long-short portfolio analysis

Panel A presents summary statistics for the excess returns of the long (L), short (S) and long-short (LS) portfolios based on speculative pressure per class of futures (commodity, currency, equity index and fixed income) and across classes (everywhere). Mean and StDev have been annualized. Newey-West h.a.c. robust $t$-statistics are reported in parentheses for the mean excess returns. Sharpe ratio is measured as Mean divided by StDev, Sortino ratio is calculated as Mean divided by annualized downside deviation and Omega ratio is measured as the probability weighted ratio of gains versus losses (the latter two ratios use $0 \%$ as threshold). CER is the certainty equivalent return that an investor with power utility preferences is willing to accept instead of engaging in the SP strategy. Panel B presents correlations between the long-short SP risk premia alongside $p$-values for the null of zero correlation in curly brackets. The sample period is October 1993 to May 2018 for the classspecific futures and October 1998 to May 2018 for the everywhere portfolio.

\begin{tabular}{|c|c|c|c|c|c|c|c|c|c|c|c|c|c|c|c|}
\hline & \multicolumn{3}{|c|}{ Commodity } & \multicolumn{3}{|c|}{ Currency } & \multicolumn{3}{|c|}{ Equity index } & \multicolumn{3}{|c|}{ Fixed income } & \multicolumn{3}{|c|}{ Everywhere } \\
\hline & $\mathrm{L}$ & $\mathrm{S}$ & LS & $\mathrm{L}$ & $\mathrm{S}$ & LS & $\mathrm{L}$ & $\mathrm{S}$ & LS & $\mathrm{L}$ & $\mathrm{S}$ & LS & $\mathrm{L}$ & $\mathrm{S}$ & LS \\
\hline \multicolumn{16}{|l|}{ Panel A: Summary statistics } \\
\hline \multirow[t]{2}{*}{ Mean } & 0.0247 & -0.0577 & 0.0412 & 0.0260 & -0.0242 & 0.0251 & 0.0529 & -0.0277 & 0.0403 & 0.0108 & 0.0255 & -0.0074 & 0.0244 & -0.0100 & 0.0172 \\
\hline & $(0.68)$ & $(-1.61)$ & $(2.62)$ & $(1.22)$ & $(-1.35)$ & $(2.45)$ & $(1.59)$ & $(-0.72)$ & $(2.29)$ & $(1.42)$ & $(2.22)$ & $(-1.49)$ & $(1.25)$ & $(-0.56)$ & $(2.57)$ \\
\hline StDev & 0.1520 & 0.1442 & 0.0673 & 0.1102 & 0.0800 & 0.0535 & 0.1554 & 0.1755 & 0.0805 & 0.0348 & 0.0577 & 0.0262 & 0.0801 & 0.0693 & 0.0314 \\
\hline \multirow[t]{2}{*}{ Skewness } & -0.3670 & -0.3312 & -0.1013 & -2.2044 & 0.0262 & -1.8077 & -0.6196 & -0.5097 & -0.1556 & -0.2985 & 0.1920 & -0.1721 & -0.8904 & -0.2506 & -0.4609 \\
\hline & $(-2.58)$ & $(-2.33)$ & $(-0.71)$ & $(-15.48)$ & $(0.18)$ & $(-12.70)$ & $(-4.35)$ & $(-3.58)$ & $(-1.09)$ & $(-2.10)$ & $(1.35)$ & $(-1.21)$ & $(-5.58)$ & $(-1.57)$ & $(-2.89)$ \\
\hline \multirow[t]{2}{*}{ Excess kurtosis } & 3.1978 & 2.1227 & 1.5172 & 16.2427 & 0.7994 & 16.4859 & 1.2954 & 1.2339 & 2.5833 & 4.2846 & 4.7036 & 5.7273 & 4.5767 & 2.4961 & 2.0399 \\
\hline & $(11.23)$ & $(7.45)$ & $(5.33)$ & (57.04) & $(2.81)$ & (57.90) & $(4.55)$ & $(4.33)$ & $(9.07)$ & $(15.05)$ & $(16.52)$ & $(20.11)$ & $(14.35)$ & $(7.83)$ & $(6.40)$ \\
\hline 99\% VaR (Cornish-Fisher) & 0.1424 & 0.1308 & 0.0500 & 0.1860 & 0.0596 & 0.0949 & 0.1275 & 0.1488 & 0.0672 & 0.0344 & 0.0523 & 0.0292 & 0.0848 & 0.0623 & 0.0263 \\
\hline$\%$ of positive months & 0.5574 & 0.4831 & 0.5574 & 0.6014 & 0.4595 & 0.6115 & 0.5878 & 0.5000 & 0.5473 & 0.5507 & 0.5743 & 0.4459 & 0.5720 & 0.4746 & 0.6017 \\
\hline Maximum drawdown & -0.4762 & -0.8334 & -0.1677 & -0.3223 & -0.5678 & -0.1642 & -0.5460 & -0.8504 & -0.2167 & -0.1095 & -0.1031 & -0.2130 & -0.2705 & -0.3884 & -0.0779 \\
\hline Sharpe ratio & 0.1624 & -0.3999 & 0.6121 & 0.2362 & -0.3026 & 0.4695 & 0.3406 & -0.1580 & 0.5010 & 0.3103 & 0.4422 & -0.2810 & 0.3041 & -0.1439 & 0.5473 \\
\hline Sortino ratio & 0.2174 & -0.5779 & 0.9416 & 0.2390 & -0.4685 & 0.5176 & 0.4489 & -0.2171 & 0.7088 & 0.3857 & 0.6031 & -0.3650 & 0.3663 & -0.2051 & 0.7255 \\
\hline Omega ratio & 1.1386 & 0.7384 & 1.5963 & 1.2304 & 0.7976 & 1.4916 & 1.2963 & 0.8871 & 1.5094 & 1.3215 & 1.4712 & 0.7783 & 1.2825 & 0.8943 & 1.5209 \\
\hline CER & -0.0368 & -0.1152 & 0.0297 & -0.0112 & -0.0405 & 0.0174 & -0.0116 & -0.1133 & 0.0239 & 0.0077 & 0.0172 & -0.0091 & 0.0075 & -0.0222 & 0.0146 \\
\hline \multicolumn{16}{|c|}{ Panel B: Correlation in the excess returns of the class-specific portfolios } \\
\hline \multirow[t]{2}{*}{ Currency } & & & -0.0094 & & & & & & & & & & & & \\
\hline & & & $\{0.87\}$ & & & & & & & & & & & & \\
\hline \multirow[t]{2}{*}{ Equity index } & & & 0.0260 & & & 0.1687 & & & & & & & & & \\
\hline & & & $\{0.66\}$ & & & $\{0.00\}$ & & & & & & & & & \\
\hline \multirow[t]{2}{*}{ Fixed income } & & & -0.0151 & & & -0.0092 & & & 0.1660 & & & & & & \\
\hline & & & $\{0.80\}$ & & & $\{0.87\}$ & & & $\{0.00\}$ & & & & & & \\
\hline
\end{tabular}


Table 3. Do speculators outperform publicly-available rule-based strategies?

This table reports the OLS coefficient estimates and Newey-West $t$-statistics from regressions of the excess returns of the long-short SP portfolio on AVG, Mom, Value and Carry where AVG is a long-only equally-weighted portfolio of the constituents of a given market, Mom, Value and Carry are long-short portfolios based on the corresponding momentum, value and carry signals. Adj- $R^{2}$ is the adjusted explanatory power statistic. The sample period is October 1993 to May 2018 for the class-specific futures portfolio analyses in columns 1-4, and October 1998 to May 2018 for the everywhere portfolio analysis in column 5.

\begin{tabular}{lccccc}
\hline & Commodity & Currency & Equity index & Fixed income & Everywhere \\
\hline$\alpha$ & 0.0023 & 0.0008 & 0.0004 & 0.0000 & 0.0008 \\
& $(1.84)$ & $(1.35)$ & $(0.43)$ & $(-0.08)$ & $(1.42)$ \\
$B_{\text {AVG }}$ & 0.0246 & 0.1012 & -0.0196 & -0.2136 & 0.1069 \\
& $(0.67)$ & $(2.16)$ & $(-0.53)$ & $(-2.49)$ & $(1.74)$ \\
$B_{\text {Mom }}$ & 0.2910 & 0.3128 & 0.2382 & -0.0191 & 0.1458 \\
& $(5.09)$ & $(4.48)$ & $(6.29)$ & $(-0.27)$ & $(2.92)$ \\
$B_{\text {Value }}$ & -0.0716 & 0.0832 & 0.0619 & -0.2021 & -0.1211 \\
& $(-1.35)$ & $(0.92)$ & $(1.17)$ & $(-2.03)$ & $(-1.61)$ \\
$B_{\text {Carry }}$ & 0.0412 & 0.2323 & 0.0287 & -0.3324 & 0.1283 \\
& $(0.99)$ & $(3.77)$ & $(0.92)$ & $(-2.71)$ & $(1.99)$ \\
Adj- $^{2}$ & 0.26 & 0.36 & 0.42 & 0.39 & 0.15 \\
\hline
\end{tabular}




\section{Table 4. Does a common factor structure explain the SP risk premia?}

Panel A reports the percentage of total variation in the excess returns of the four class-specific SP portfolios that each principal component (PC) explains. Panel B reports the OLS coefficient estimates and Newey-West $t$-statistics from regressions of the SP excess returns on business cycle variables (change in industrial production, IP; default spread, DS; term spread, TS; Kilian's global real economic activity index), market liquidity shocks $(L)$, funding liquidity shocks (TED) and volatility shocks $(v)$. Adj- $R^{2}$ is the degrees-of-freedom adjusted coefficient of determination (explanatory power). The sample period is October 1993 to May 2018.

\begin{tabular}{|c|c|c|c|c|}
\hline \multicolumn{5}{|c|}{ Panel A: Principal component analysis } \\
\hline & 1st PC & 2nd PC & 3rd PC & 4th PC \\
\hline Variance explained & $30.81 \%$ & $25.29 \%$ & $25.04 \%$ & $18.87 \%$ \\
\hline \multicolumn{5}{|c|}{ Panel B: Macroeconomic, liquidity and volatility risks } \\
\hline & Commodity & Currency & Equity index & Fixed income \\
\hline \multirow[t]{2}{*}{$\alpha$} & -0.0005 & 0.0072 & -0.0125 & 0.0030 \\
\hline & $(-0.12)$ & $(2.38)$ & $(-2.66)$ & $(2.11)$ \\
\hline \multirow[t]{2}{*}{$B_{I P}$} & -0.0903 & -0.1057 & 0.2208 & -0.0009 \\
\hline & $(-0.31)$ & $(-0.73)$ & $(1.05)$ & $(-0.01)$ \\
\hline \multirow[t]{2}{*}{$B_{D S}$} & 0.0042 & -0.0028 & 0.0097 & -0.0028 \\
\hline & $(1.22)$ & $(-1.33)$ & $(2.72)$ & $(-2.53)$ \\
\hline \multirow[t]{2}{*}{$B_{T S}$} & -0.0012 & -0.0005 & 0.0008 & 0.0003 \\
\hline & $(-0.84)$ & $(-0.53)$ & $(0.69)$ & $(0.85)$ \\
\hline \multirow[t]{2}{*}{$B_{\text {Kilian }}$} & 0.0000 & 0.0000 & 0.0000 & 0.0000 \\
\hline & (1.39) & $(0.22)$ & $(-1.05)$ & $(-1.37)$ \\
\hline \multirow[t]{2}{*}{$b_{L}$} & 0.0001 & 0.0002 & 0.0004 & 0.0001 \\
\hline & $(0.49)$ & $(1.81)$ & (1.49) & (1.23) \\
\hline \multirow[t]{2}{*}{$B_{\text {TED }}$} & -0.0070 & -0.0055 & 0.0091 & 0.0004 \\
\hline & $(-0.77)$ & $(-1.48)$ & (1.99) & $(0.27)$ \\
\hline \multirow[t]{2}{*}{$b_{v}$} & -0.1058 & -0.2103 & -0.6488 & 0.0181 \\
\hline & $(-1.56)$ & $(-2.21)$ & $(-4.15)$ & $(0.45)$ \\
\hline Adj- $R^{2}$ & 0.00 & 0.05 & 0.15 & 0.00 \\
\hline
\end{tabular}


Table 5. Cross-sectional pricing ability of the speculative pressure risk factors

This table reports the average price $(\lambda)$ and Shanken-corrected $t$-statistics in parentheses for the risk factors. The pricing ability of the classspecific and 'everywhere' speculative pressure (SP) risk factors is tested individually (column 1 of each panel), jointly with the corresponding AVG, Mom, Value and Carry risk factors (column 2 of each panel), and jointly with business cycle variables such as the change in industrial production, IP, the default spread, DS, the term spread, TS, the Kilian's index of global real economic activity, market liquidity shocks, $L$, funding liquidity shocks, TED, and volatility shocks, $v$ (column 3 of each panel). The test assets are the 84 individual futures contracts throughout. Adj- $R^{2}\left(\Delta a d j .-R^{2}\right)$ is the explanatory power (incremental explanatory power) of the SP risk factor. The sample period is October 1993 to May 2018 for the class-specific futures analyses and October 1998 to May 2018 for the everywhere futures analysis.

\begin{tabular}{|c|c|c|c|c|c|c|c|c|c|c|c|c|c|c|c|}
\hline \multirow[b]{2}{*}{$\lambda_{0}$} & \multicolumn{3}{|c|}{ Commodity } & \multicolumn{3}{|c|}{ Currency } & \multicolumn{3}{|c|}{ Equity index } & \multicolumn{3}{|c|}{ Fixed income } & \multicolumn{3}{|c|}{ Everywhere } \\
\hline & -0.0004 & -0.0006 & -0.0014 & -0.0015 & -0.0016 & -0.0016 & -0.0008 & -0.0016 & -0.0015 & 0.0000 & 0.0000 & -0.0012 & -0.0016 & -0.0011 & -0.0015 \\
\hline & $(-0.30)$ & $(-0.69)$ & $(-1.31)$ & $(-1.32)$ & $(-1.66)$ & $(-1.67)$ & $(-0.62)$ & $(-1.67)$ & $(-1.54)$ & $(0.01)$ & $(-0.03)$ & $(-1.24)$ & $(-1.22)$ & $(-1.08)$ & $(-1.43)$ \\
\hline \multirow[t]{2}{*}{$\lambda_{S P}$} & 0.0052 & 0.0050 & 0.0062 & 0.0038 & 0.0048 & 0.0036 & 0.0049 & 0.0055 & 0.0050 & 0.0029 & 0.0005 & 0.0009 & 0.0031 & 0.0031 & 0.0042 \\
\hline & $(2.32)$ & $(2.18)$ & $(2.17)$ & $(2.57)$ & $(2.76)$ & $(1.92)$ & $(2.14)$ & $(2.34)$ & $(1.71)$ & $(2.32)$ & $(0.47)$ & $(0.80)$ & $(2.83)$ & $(2.44)$ & (3.01) \\
\hline \multirow[t]{2}{*}{$\lambda_{\mathrm{AVG}}$} & & 0.0015 & & & 0.0017 & & & 0.0049 & & & -0.0009 & & & 0.0000 & \\
\hline & & $(0.65)$ & & & $(0.95)$ & & & $(1.83)$ & & & $(-0.95)$ & & & $(0.00)$ & \\
\hline \multirow[t]{2}{*}{$\lambda_{\mathrm{Mom}}$} & & 0.0028 & & & 0.0019 & & & 0.0173 & & & 0.0007 & & & 0.0039 & \\
\hline & & $(0.60)$ & & & $(0.62)$ & & & $(2.21)$ & & & $(0.43)$ & & & $(1.53)$ & \\
\hline \multirow[t]{2}{*}{$\lambda_{\text {Value }}$} & & -0.0035 & & & 0.0002 & & & -0.0048 & & & 0.0001 & & & 0.0004 & \\
\hline & & $(-0.98)$ & & & $(0.11)$ & & & $(-0.79)$ & & & $(0.07)$ & & & $(0.26)$ & \\
\hline \multirow[t]{2}{*}{$\lambda_{\text {Carry }}$} & & -0.0030 & & & 0.0032 & & & 0.0050 & & & 0.0002 & & & 0.0041 & \\
\hline & & $(-0.55)$ & & & $(1.12)$ & & & $(0.52)$ & & & $(0.18)$ & & & $(2.06)$ & \\
\hline \multirow[t]{2}{*}{$\lambda_{\mathrm{IP}}$} & & & -0.0016 & & & -0.0025 & & & -0.0028 & & & -0.0024 & & & -0.0010 \\
\hline & & & $(-1.23)$ & & & $(-2.07)$ & & & $(-2.26)$ & & & $(-1.94)$ & & & $(-0.79)$ \\
\hline \multirow[t]{2}{*}{$\lambda_{\mathrm{DS}}$} & & & 0.1646 & & & 0.1929 & & & 0.1250 & & & 0.1697 & & & 0.0469 \\
\hline & & & $(1.97)$ & & & $(2.51)$ & & & $(1.63)$ & & & $(2.24)$ & & & $(0.55)$ \\
\hline \multirow[t]{2}{*}{$\lambda_{\mathrm{TS}}$} & & & 0.2981 & & & 0.2479 & & & 0.2003 & & & 0.2844 & & & 0.0540 \\
\hline & & & (1.49) & & & $(1.26)$ & & & $(1.06)$ & & & (1.47) & & & $(0.20)$ \\
\hline \multirow[t]{2}{*}{$\lambda_{\text {Kilian }}$} & & & -16.4343 & & & -6.0556 & & & 0.1156 & & & -3.5666 & & & -11.1081 \\
\hline & & & $(-1.11)$ & & & $(-0.45)$ & & & $(0.01)$ & & & $(-0.27)$ & & & $(-0.85)$ \\
\hline \multirow[t]{2}{*}{$\lambda_{\mathrm{L}}$} & & & 3.0490 & & & 2.3481 & & & 2.3152 & & & 2.2416 & & & 2.1911 \\
\hline & & & $(2.14)$ & & & $(1.81)$ & & & $(1.71)$ & & & $(1.61)$ & & & (1.48) \\
\hline \multirow[t]{2}{*}{$\lambda_{\text {TED }}$} & & & 0.0375 & & & -0.0271 & & & -0.0305 & & & -0.0379 & & & 0.0331 \\
\hline & & & $(0.84)$ & & & $(-0.65)$ & & & $(-0.74)$ & & & $(-0.94)$ & & & $(0.83)$ \\
\hline \multirow[t]{2}{*}{$\lambda_{v}$} & & & -0.0028 & & & -0.0014 & & & -0.0014 & & & -0.0017 & & & -0.0020 \\
\hline & & & $(-1.55)$ & & & $(-0.79)$ & & & $(-0.81)$ & & & $(-1.04)$ & & & $(-1.05)$ \\
\hline $\operatorname{Adj}-R^{2}$ & 0.05 & 0.24 & 0.25 & 0.07 & 0.17 & 0.23 & 0.06 & 0.18 & 0.24 & 0.06 & 0.17 & 0.23 & 0.07 & 0.20 & 0.23 \\
\hline$\Delta \operatorname{adj-R^{2}}$ & & 0.04 & 0.03 & & 0.03 & 0.01 & & 0.01 & 0.02 & & 0.02 & 0.01 & & 0.04 & 0.01 \\
\hline
\end{tabular}


Table 6. Commitments of Traders reports

The table reports robustness tests for the long-short portfolios (Panel A) and cross-sectional pricing (Panel B) as regards alternative speculative pressure signals based on: $i$ ) hedging pressure or the standardized net positions of commercial traders as reported in the Futures-Only Legacy COT report, ii) the standardized net positions of non-commercial traders as reported in the Futures and Options Legacy COT report, or iii) the standardized net positions of managed money managers and levered fund managers as reported the Disaggregated COT and TFF reports. Mean is the annualized mean excess return. Sharpe ratio is the Mean divided by annualized standard deviation, Sortino ratio is the Mean divided by annualized downside deviation and Omega ratio is the probability weighted ratio of gains versus losses; the latter two ratios use a $0 \%$ threshold. CER is the certainty equivalent return that an investor with power utility preferences is willing to accept instead of engaging in a given strategy. $\alpha$ and $\beta$ are the intercept and slope coefficient estimated from a regression of the excess returns of a given alternative SP portfolio on the excess returns of the corresponding baseline SP portfolio. Adj- $R^{2}$ is the corresponding adjusted-goodness of fit statistics. $\lambda_{S P}$ is the average price of SP risk as estimated within an augmented pricing model that also includes off-the-shelf risk factors. $\Delta$ adj $-R^{2}$ denotes the incremental explanatory power of the SP risk factor. The $t$-statistics in parentheses are Newey-West corrected in Panel A and Shanken corrected in Panel B. The sample period for the class-specific portfolios starts October 1993 for the hedging pressure signal based on the Futures-Only Legacy COT report, March 1996 for the SP signal based on the Futures-and-Options Legacy COT report and June 2007 for the Disaggregated COT and TFF reports. The everywhere portfolio returns start 60 months later. All the samples end in May 2018.

\begin{tabular}{|c|c|c|c|c|c|c|c|c|c|c|c|c|c|c|c|}
\hline & \multicolumn{5}{|c|}{ Hedging pressure } & \multicolumn{5}{|c|}{ Combined futures and options COT report } & \multicolumn{5}{|c|}{ Disaggregated COT and TFF reports } \\
\hline & Comm. & Currency & $\begin{array}{l}\text { Equity } \\
\text { indices }\end{array}$ & $\begin{array}{c}\text { Fixed } \\
\text { income }\end{array}$ & $\begin{array}{l}\text { Every- } \\
\text { where }\end{array}$ & Comm. & Currency & $\begin{array}{l}\text { Equity } \\
\text { indices }\end{array}$ & $\begin{array}{c}\text { Fixed } \\
\text { income }\end{array}$ & $\begin{array}{l}\text { Every- } \\
\text { where }\end{array}$ & Comm. & Currency & $\begin{array}{l}\text { Equity } \\
\text { indices }\end{array}$ & $\begin{array}{c}\text { Fixed } \\
\text { income }\end{array}$ & $\begin{array}{l}\text { Every- } \\
\text { where }\end{array}$ \\
\hline \multicolumn{16}{|c|}{ Panel A: Long-short portfolio results } \\
\hline Mean & $\begin{array}{r}0.0394 \\
(2.52)\end{array}$ & $\begin{array}{r}0.0219 \\
(2.24)\end{array}$ & $\begin{array}{r}0.0461 \\
(2.14)\end{array}$ & $\begin{array}{r}-0.0086 \\
(-1.93)\end{array}$ & $\begin{array}{r}0.0226 \\
(3.17)\end{array}$ & $\begin{array}{r}0.0490 \\
(3.18)\end{array}$ & $\begin{array}{r}0.0232 \\
(2.19)\end{array}$ & $\begin{array}{r}0.0388 \\
(2.08)\end{array}$ & $\begin{array}{r}-0.0074 \\
(-1.36)\end{array}$ & $\begin{array}{r}0.0205 \\
(2.74)\end{array}$ & $\begin{array}{r}0.0574 \\
(2.29)\end{array}$ & $\begin{array}{r}-0.0119 \\
(-0.87)\end{array}$ & $\begin{array}{r}0.1464 \\
(3.82)\end{array}$ & $\begin{array}{r}-0.0181 \\
(-1.46)\end{array}$ & $\begin{array}{r}0.0376 \\
(3.69)\end{array}$ \\
\hline Sharpe ratio & 0.5348 & 0.4655 & 0.4487 & -0.3480 & 0.6108 & 0.7195 & 0.4294 & 0.4648 & -0.2747 & 0.6305 & 0.7823 & -0.2832 & 1.2768 & -0.4456 & 1.4456 \\
\hline Sortino ratio & 0.9833 & 0.6216 & 0.5873 & -0.4433 & 0.7303 & 1.1545 & 0.4487 & 0.6616 & -0.3532 & 0.7873 & 1.4100 & -0.3704 & 2.1923 & -0.5460 & 1.8066 \\
\hline Omega ratio & 1.4846 & 1.4320 & 1.5066 & 0.7312 & 1.6778 & 1.7321 & 1.4515 & 1.4554 & 0.7806 & 1.6498 & 1.8246 & 0.8056 & 2.9015 & 0.6923 & 2.8977 \\
\hline CER & 0.0259 & 0.0162 & 0.0179 & -0.0102 & 0.0191 & 0.0372 & 0.0152 & 0.0212 & -0.0093 & 0.0178 & 0.0439 & -0.0165 & 0.1132 & -0.0224 & 0.0357 \\
\hline$\alpha$ & $\begin{array}{r}0.0007 \\
(0.70)\end{array}$ & $\begin{array}{r}0.0001 \\
(0.37)\end{array}$ & $\begin{array}{r}0.0002 \\
(0.17)\end{array}$ & $\begin{array}{r}-0.0002 \\
(-1.00)\end{array}$ & $\begin{array}{r}0.0006 \\
(1.13)\end{array}$ & $\begin{array}{r}0.0008 \\
(1.58)\end{array}$ & $\begin{array}{l}0.0000 \\
(-0.37)\end{array}$ & $\begin{array}{r}-0.0005 \\
(-1.69)\end{array}$ & $\begin{array}{r}-0.0001 \\
(-1.07)\end{array}$ & $\begin{array}{l}0.0000 \\
(-0.02)\end{array}$ & $\begin{array}{r}0.0005 \\
(0.41)\end{array}$ & $\begin{array}{r}-0.0013 \\
(-2.20)\end{array}$ & $\begin{array}{r}0.0061 \\
(2.34)\end{array}$ & $\begin{array}{r}-0.0008 \\
(-1.07)\end{array}$ & $\begin{array}{r}0.0020 \\
(2.59)\end{array}$ \\
\hline B & $\begin{array}{l}0.7649 \\
(11.43)\end{array}$ & $\begin{array}{l}0.8100 \\
(10.54)\end{array}$ & $\begin{array}{r}1.0934 \\
(9.82)\end{array}$ & $\begin{array}{l}0.8170 \\
(11.56)\end{array}$ & $\begin{array}{r}0.9163 \\
(9.33)\end{array}$ & $\begin{array}{l}0.9078 \\
(28.65)\end{array}$ & $\begin{array}{l}1.0051 \\
(61.04)\end{array}$ & $\begin{array}{l}0.9833 \\
(72.68)\end{array}$ & $\begin{array}{l}0.9822 \\
(78.65)\end{array}$ & $\begin{array}{l}0.9993 \\
(25.48)\end{array}$ & $\begin{array}{l}0.9752 \\
(16.77)\end{array}$ & $\begin{array}{l}0.8403 \\
(11.69)\end{array}$ & $\begin{array}{l}0.8018 \\
(18.80)\end{array}$ & $\begin{array}{r}0.9322 \\
(5.04)\end{array}$ & $\begin{array}{r}0.6437 \\
(4.53)\end{array}$ \\
\hline $\operatorname{Adj}-R^{2}$ & 0.49 & 0.85 & 0.73 & 0.74 & 0.60 & 0.83 & 0.99 & 0.98 & 0.99 & 0.91 & 0.73 & 0.75 & 0.51 & 0.50 & 0.45 \\
\hline \multicolumn{16}{|c|}{ Panel B: Cross-sectional pricing results } \\
\hline$\lambda_{\mathrm{SP}}$ & $\begin{array}{r}0.0042 \\
(2.26)\end{array}$ & $\begin{array}{r}0.0037 \\
(2.45)\end{array}$ & $\begin{array}{r}0.0078 \\
(1.84)\end{array}$ & $\begin{array}{r}-0.0003 \\
(-0.26)\end{array}$ & $\begin{array}{r}0.0032 \\
(2.88)\end{array}$ & $\begin{array}{r}0.0059 \\
(2.45)\end{array}$ & $\begin{array}{r}0.0051 \\
(2.89)\end{array}$ & $\begin{array}{r}0.0050 \\
(1.99)\end{array}$ & $\begin{array}{r}0.0010 \\
(1.01)\end{array}$ & $\begin{array}{r}0.0035 \\
(2.78)\end{array}$ & $\begin{array}{r}0.0064 \\
(2.78)\end{array}$ & $\begin{array}{r}0.0045 \\
(3.01)\end{array}$ & $\begin{array}{r}0.0103 \\
(2.02)\end{array}$ & $\begin{array}{r}0.0014 \\
(1.07)\end{array}$ & $\begin{array}{r}0.0030 \\
(2.90)\end{array}$ \\
\hline$\Delta \mathrm{adj}-R^{2}$ & 0.06 & 0.03 & 0.02 & 0.02 & 0.05 & 0.04 & 0.03 & 0.01 & 0.01 & 0.06 & 0.03 & 0.04 & 0.04 & 0.04 & 0.06 \\
\hline
\end{tabular}


Table 7. Alternative portfolio construction techniques

The table reports robustness tests for the long-short portfolios (Panel A) and cross-sectional pricing (Panel B) as regards the use of terciles and asset weighting scheme. Mean is the annualized mean excess return. Sharpe ratio is the Mean divided by annualized standard deviation, Sortino ratio is the Mean divided by annualized downside deviation and Omega ratio is the probability weighted ratio of gains versus losses; the latter two ratios are based on a $0 \%$ threshold. CER is the certainty equivalent return that an investor with power utility preferences is willing to accept instead of engaging in a given strategy. $\alpha$ and $\beta$ are the intercept and slope coefficient estimated from a regression of the excess returns of a given alternative SP portfolio on the excess returns of the corresponding benchmark SP portfolio. $\operatorname{Adj}-R^{2}$ is the corresponding adjusted-goodness of fit statistics. $\lambda_{S P}$ is the average price of SP risk as estimated within an augmented pricing model that also includes off-the-shelf risk factors. $\Delta$ adj $-R^{2}$ denotes the incremental explanatory power of the SP risk factor. The $t$-statistics in parentheses are Newey-West corrected in Panel A and Shanken corrected in Panel B. The sample period is October 1993 to May 2018 for the class-specific futures portfolios, and October 1998 to May 2018 for the 'everywhere’ futures portfolios.

\begin{tabular}{|c|c|c|c|c|c|c|c|c|c|c|c|c|c|c|c|c|c|c|c|c|}
\hline \multirow{3}{*}{$\begin{array}{l}\text { Constituents } \\
\text { Weights } \\
\end{array}$} & \multirow{2}{*}{\multicolumn{5}{|c|}{$\begin{array}{c}\text { Top and bottom terciles } \\
\text { Standardized signal }\end{array}$}} & \multicolumn{15}{|c|}{$100 \%$ of the available cross section } \\
\hline & & & & & & \multicolumn{5}{|c|}{ Standardized ranking } & \multicolumn{5}{|c|}{$\begin{array}{l}\text { Equal weighting } \\
\end{array}$} & \multicolumn{5}{|c|}{ Risk parity weighting } \\
\hline & Comm. & Currency & $\begin{array}{l}\text { Equity } \\
\text { indices }\end{array}$ & $\begin{array}{l}\text { Fixed } \\
\text { income }\end{array}$ & $\begin{array}{l}\text { Every- } \\
\text { where }\end{array}$ & Comm. & Currency & $\begin{array}{l}\text { Equity } \\
\text { indices }\end{array}$ & $\begin{array}{c}\text { Fixed } \\
\text { income }\end{array}$ & $\begin{array}{l}\text { Every- } \\
\text { where }\end{array}$ & Comm. & Currency & $\begin{array}{l}\text { Equity } \\
\text { indices }\end{array}$ & $\begin{array}{c}\text { Fixed } \\
\text { income }\end{array}$ & $\begin{array}{l}\text { Every- } \\
\text { where }\end{array}$ & Comm. & $\begin{array}{c}\text { Currenc } \\
y \\
\end{array}$ & $\begin{array}{l}\text { Equity } \\
\text { indices }\end{array}$ & $\begin{array}{c}\text { Fixed } \\
\text { income }\end{array}$ & $\begin{array}{l}\text { Every- } \\
\text { where }\end{array}$ \\
\hline \multicolumn{21}{|c|}{ Panel A: Long-short portfolio results } \\
\hline Mean & $\begin{array}{r}0.0441 \\
(2.60)\end{array}$ & $\begin{array}{r}0.0286 \\
(2.51)\end{array}$ & $\begin{array}{r}0.0424 \\
(2.22)\end{array}$ & $\begin{array}{r}-0.0069 \\
(-1.30)\end{array}$ & $\begin{array}{r}0.0188 \\
(2.41)\end{array}$ & $\begin{array}{r}0.0330 \\
(2.20)\end{array}$ & $\begin{array}{r}0.0248 \\
(2.58)\end{array}$ & $\begin{array}{r}0.0307 \\
(1.93)\end{array}$ & $\begin{array}{r}-0.0069 \\
(-1.39)\end{array}$ & $\begin{array}{r}0.0226 \\
(3.17)\end{array}$ & $\begin{array}{r}0.0278 \\
(2.19)\end{array}$ & $\begin{array}{r}0.0217 \\
(2.72)\end{array}$ & $\begin{array}{r}0.0160 \\
(1.18)\end{array}$ & $\begin{array}{r}-0.0059 \\
(-1.30)\end{array}$ & $\begin{array}{r}0.0097 \\
(1.92)\end{array}$ & $\begin{array}{r}0.0332 \\
(2.16)\end{array}$ & $\begin{array}{r}0.0184 \\
(2.01)\end{array}$ & $\begin{array}{r}0.0296 \\
(2.06)\end{array}$ & $\begin{array}{r}-0.0059 \\
(-1.30)\end{array}$ & $\begin{array}{r}0.0133 \\
(2.07)\end{array}$ \\
\hline Sharpe ratio & 0.6078 & 0.4674 & 0.4779 & -0.2382 & 0.5268 & 0.5134 & 0.4833 & 0.4181 & -0.2649 & 0.6108 & 0.4966 & 0.5285 & 0.2663 & -0.2706 & 0.3931 & 0.4775 & 0.4094 & 0.4174 & -0.2591 & 0.4510 \\
\hline Sortino ratio & 0.9256 & 0.4882 & 0.6753 & -0.3164 & 0.6771 & 0.7948 & 0.5206 & 0.5878 & -0.3419 & 0.7303 & 0.7307 & 0.6355 & 0.3521 & -0.3387 & 0.4683 & 0.8780 & 0.5232 & 0.6160 & -0.3376 & 0.6470 \\
\hline Omega ratio & 1.5924 & 1.5015 & 1.4782 & 0.8086 & 1.5107 & 1.4877 & 1.5116 & 1.4016 & 0.7871 & 1.6778 & 1.4716 & 1.5483 & 1.2381 & 0.7834 & 1.3627 & 1.4291 & 1.3744 & 1.4137 & 0.8018 & 1.4073 \\
\hline CER & 0.0307 & 0.0180 & 0.0225 & -0.0090 & 0.0156 & 0.0226 & 0.0177 & 0.0170 & -0.0087 & 0.0191 & 0.0199 & 0.0173 & 0.0068 & -0.0071 & 0.0081 & 0.0212 & 0.0132 & 0.0169 & -0.0072 & 0.0111 \\
\hline$\alpha$ & $\begin{array}{r}0.0000 \\
(0.15)\end{array}$ & $\begin{array}{r}0.0000 \\
(0.11)\end{array}$ & $\begin{array}{r}-0.0001 \\
(-0.46)\end{array}$ & $\begin{array}{r}0.0001 \\
(1.12)\end{array}$ & $\begin{array}{l}0.0000 \\
(-0.15)\end{array}$ & $\begin{array}{r}-0.0004 \\
(-1.95)\end{array}$ & $\begin{array}{r}0.0001 \\
(0.52)\end{array}$ & $\begin{array}{r}-0.0004 \\
(-1.53)\end{array}$ & $\begin{array}{r}0.0000 \\
(0.34)\end{array}$ & $\begin{array}{r}-0.0001 \\
(-0.60)\end{array}$ & $\begin{array}{r}-0.0002 \\
(-0.47)\end{array}$ & $\begin{array}{r}0.0003 \\
(1.24)\end{array}$ & $\begin{array}{r}-0.0008 \\
(-1.33)\end{array}$ & $\begin{array}{l}0.0000 \\
(-0.08)\end{array}$ & $\begin{array}{r}-0.0001 \\
(-0.22)\end{array}$ & $\begin{array}{r}0.0005 \\
(0.50)\end{array}$ & $\begin{array}{r}-0.0001 \\
(-0.15)\end{array}$ & $\begin{array}{r}0.0000 \\
(0.00)\end{array}$ & $\begin{array}{r}-0.0001 \\
(-0.32)\end{array}$ & $\begin{array}{r}0.0002 \\
(0.47)\end{array}$ \\
\hline b & $\begin{array}{l}1.0613 \\
(73.82)\end{array}$ & $\begin{array}{l}1.1274 \\
(29.73)\end{array}$ & $\begin{array}{l}1.0870 \\
(70.92)\end{array}$ & $\begin{array}{l}1.0867 \\
(28.03)\end{array}$ & $\begin{array}{l}1.1140 \\
(44.54)\end{array}$ & $\begin{array}{l}0.9281 \\
(46.28)\end{array}$ & $\begin{array}{l}0.9399 \\
(49.64)\end{array}$ & $\begin{array}{l}0.8929 \\
(42.33)\end{array}$ & $\begin{array}{l}0.9849 \\
(67.30)\end{array}$ & $\begin{array}{l}0.9382 \\
(26.39)\end{array}$ & $\begin{array}{l}0.7353 \\
(23.76)\end{array}$ & $\begin{array}{l}0.7005 \\
(23.19)\end{array}$ & $\begin{array}{l}0.6331 \\
(16.48)\end{array}$ & $\begin{array}{l}0.7857 \\
(20.32)\end{array}$ & $\begin{array}{c}0.6098 \\
(11.34)\end{array}$ & $\begin{array}{r}0.6623 \\
(8.74)\end{array}$ & $\begin{array}{c}0.7573 \\
(10.57)\end{array}$ & $\begin{array}{l}0.7320 \\
(13.89)\end{array}$ & $\begin{array}{l}0.6591 \\
(12.67)\end{array}$ & $\begin{array}{r}0.6309 \\
(7.94)\end{array}$ \\
\hline Adj- $R^{2}$ & 0.97 & 0.97 & 0.97 & 0.97 & 0.95 & 0.94 & 0.96 & 0.96 & 0.97 & 0.89 & 0.78 & 0.83 & 0.72 & 0.89 & 0.60 & 0.41 & 0.81 & 0.69 & 0.58 & 0.45 \\
\hline \multicolumn{21}{|c|}{ Panel B: Cross-sectional pricing results } \\
\hline$\lambda_{s p}$ & $\begin{array}{r}0.0059 \\
(2.25)\end{array}$ & $\begin{array}{r}0.0057 \\
(2.85)\end{array}$ & $\begin{array}{r}0.0069 \\
(2.42)\end{array}$ & $\begin{array}{r}0.0004 \\
(0.41)\end{array}$ & $\begin{array}{r}0.0029 \\
(2.29)\end{array}$ & $\begin{array}{r}0.0039 \\
(1.77)\end{array}$ & $\begin{array}{r}0.0040 \\
(2.27)\end{array}$ & $\begin{array}{r}0.0055 \\
(2.33)\end{array}$ & $\begin{array}{r}0.0005 \\
(0.50)\end{array}$ & $\begin{array}{r}0.0026 \\
(2.42)\end{array}$ & $\begin{array}{r}0.0027 \\
(1.39)\end{array}$ & $\begin{array}{r}0.0027 \\
(1.60)\end{array}$ & $\begin{array}{r}0.0039 \\
(2.08)\end{array}$ & $\begin{array}{r}0.0007 \\
(0.75)\end{array}$ & $\begin{array}{r}0.0022 \\
(2.22)\end{array}$ & $\begin{array}{r}0.0036 \\
(2.12)\end{array}$ & $\begin{array}{r}0.0043 \\
(2.72)\end{array}$ & $\begin{array}{r}0.0059 \\
(1.78)\end{array}$ & $\begin{array}{r}0.0014 \\
(1.20)\end{array}$ & $\begin{array}{r}0.0040 \\
(3.25)\end{array}$ \\
\hline$\Delta \operatorname{adj}-R^{2}$ & 0.04 & 0.02 & 0.01 & 0.01 & 0.04 & 0.03 & 0.02 & 0.02 & 0.02 & 0.03 & 0.03 & 0.02 & 0.02 & 0.02 & 0.02 & 0.04 & 0.03 & 0.03 & 0.02 & 0.04 \\
\hline
\end{tabular}


Table 8. Transaction costs analysis

The table reports for each long-short portfolio strategy the turnover measure, Equation (6), and the break-even round-trip transaction cost that makes the Sharpe ratio equal to zero, Equation (7). The sample period is October 1993 to May 2018 for the class-specific futures portfolios and October 1998 to May 2018 for the 'everywhere’ futures portfolios.

\begin{tabular}{lccccc}
\hline & Commodity & Currency & Equity index & Fixed income & Everywhere \\
\hline & & & & & \\
Panel A: Speculative pressure & 0.1465 & 0.1476 & 0.1439 & 0.1436 & 0.2303 \\
Turnover & 2.351 & 1.423 & 2.344 & - & 0.538 \\
Break-even TC (\%) & & & & \\
& & & & & \\
Panel B: Momentum & 0.3903 & 0.3716 & 0.3248 & 0.3463 & 0.4546 \\
Turnover & 1.002 & 0.169 & 3.571 & 0.022 & 0.214 \\
Break-even TC (\%) & & & & & \\
& & & & & 0.2450 \\
Panel C: Value & 0.2474 & 0.1547 & 0.1130 & 0.1352 & 0.405 \\
Turnover & 0.805 & 1.595 & 0.000 & 0.048 & \\
Break-even TC (\%) & & & & & \\
Panel C: Carry & 0.8022 & 0.1636 & 0.4795 & 0.3937 & 0.4901 \\
Turnover & 0.500 & 1.932 & 2.893 & 0.174 & 0.573 \\
Break-even TC (\%) & & & & & \\
\hline
\end{tabular}


Table 9. Liquidity of individual futures contracts

The table reports summary statistics for the portfolios implemented on the whole cross-sections (Panel A), and on the 90\% (Panel B), and 80\% most liquid futures contracts (Panel C) as signaled by the total open interest at the time of portfolio formation. Mean is the annualized mean excess return. Sharpe ratio is the Mean divided by annualized standard deviation, Sortino ratio is calculated as Mean divided by annualized downside deviation and Omega ratio is measured as the probability weighted ratio of gains versus losses (the latter two ratios use $0 \%$ as threshold). CER is the certainty equivalent return that an investor with power utility preferences is willing to accept instead of engaging in a given strategy. The sample period is October 1993 to May 2018 for the class-specific portfolios and October 1998 to May 2018 for the 'everywhere' portfolios.

\begin{tabular}{|c|c|c|c|c|c|}
\hline & Commodity & Currency & Equity index & Fixed income & Everywhere \\
\hline \multicolumn{6}{|c|}{ Panel A: Entire cross-section of futures } \\
\hline \multirow[t]{2}{*}{ Mean } & 0.0412 & 0.0251 & 0.0403 & -0.0074 & 0.0172 \\
\hline & $(2.62)$ & $(2.45)$ & $(2.29)$ & $(-1.49)$ & $(2.57)$ \\
\hline Sharpe ratio & 0.6121 & 0.4695 & 0.5010 & -0.2810 & 0.5473 \\
\hline Sortino ratio & 0.9416 & 0.5176 & 0.7088 & -0.3650 & 0.7255 \\
\hline Omega ratio & 1.5963 & 1.4916 & 1.5094 & 0.7783 & 1.5209 \\
\hline CER & 0.0297 & 0.0174 & 0.0239 & -0.0091 & 0.0146 \\
\hline \multicolumn{6}{|c|}{ Panel B: $90 \%$ most liquid futures } \\
\hline \multirow[t]{2}{*}{ Mean } & 0.0392 & 0.0255 & 0.0373 & -0.0047 & 0.0196 \\
\hline & $(2.37)$ & $(3.06)$ & $(1.91)$ & $(-0.93)$ & $(3.06)$ \\
\hline Sharpe ratio & 0.5589 & 0.6024 & 0.4372 & -0.1767 & 0.6523 \\
\hline Sortino ratio & 0.8636 & 0.9198 & 0.6196 & -0.2454 & 0.9309 \\
\hline Omega ratio & 1.5252 & 1.5854 & 1.4388 & 0.8585 & 1.6563 \\
\hline CER & 0.0267 & 0.0210 & 0.0189 & -0.0064 & 0.0173 \\
\hline \multicolumn{6}{|c|}{ Panel C: $\mathbf{8 0 \%}$ most liquid futures } \\
\hline \multirow[t]{2}{*}{ Mean } & 0.0426 & 0.0273 & 0.0417 & -0.0039 & 0.0209 \\
\hline & $(2.60)$ & $(3.40)$ & $(2.09)$ & $(-0.78)$ & (2.99) \\
\hline Sharpe ratio & 0.5841 & 0.6495 & 0.4745 & -0.1491 & 0.6596 \\
\hline Sortino ratio & 0.8407 & 0.9988 & 0.6695 & -0.2059 & 0.9376 \\
\hline Omega ratio & 1.5607 & 1.6484 & 1.5063 & 0.8792 & 1.7081 \\
\hline CER & 0.0290 & 0.0228 & 0.0221 & -0.0056 & 0.0183 \\
\hline
\end{tabular}


Table 10. Sharpe ratios of speculative pressure portfolios in different sample periods

The table reports the Sharpe ratios over the full sample period (October 1993 to May 2018 for the futures class-specific portfolios, and October 1998 to May 2018 for the 'everywhere' futures portfolio), and sub-periods thereof; high versus low volatility months according to GARCH models fitted to the class-specific and everywhere AVG returns, NBER-dated recession and expansion months, pre and post Dodd-Frank Wall Street Reform Act (July 2010), pre and post U.S. Quantitative Easing (December 2008), and non-overlapping 5-year windows.

\begin{tabular}{lccccc}
\hline & Commodity & Currency & Equity indices & Fixed income & Everywhere \\
\cline { 2 - 6 } Full sample & 0.6121 & 0.4695 & 0.5010 & -0.2810 & 0.5473 \\
High-volatility regime & 0.9050 & 0.1496 & 0.8291 & -0.3713 & 0.7323 \\
Low-volatility regime & 0.5042 & 0.7182 & 0.3604 & -0.2401 & 0.4080 \\
Recession regime & 1.5150 & -0.4109 & -0.1512 & -0.1215 & 0.8427 \\
Expansion regime & 0.4890 & 0.5638 & 0.5498 & -0.3194 & 0.4976 \\
Pre Dodd-Frank (July 2010) & 0.7146 & 0.5379 & -0.0701 & -0.3395 & 0.2996 \\
Post Dodd-Frank & 0.3354 & 0.2811 & 1.1943 & -0.1503 & 0.9432 \\
Pre Quantitative Easing (Dec 2008) & 0.5378 & 0.5352 & -0.0515 & -0.3468 & 0.0457 \\
Post Quantitative Easing & 0.7532 & 0.3391 & 1.0055 & -0.2014 & 1.0709 \\
$31 / 10 / 1993$ to 30/09/1998 & 0.5220 & 0.8734 & -0.6139 & 0.2487 & - \\
$31 / 10 / 1998$ to 30/09/2003 & 0.4249 & 0.4875 & 0.8878 & -0.6614 & -0.1924 \\
$31 / 10 / 2003$ to 30/09/2008 & 0.6526 & 0.5419 & -0.6603 & -0.2707 & 0.3902 \\
$31 / 10 / 2008$ to 30/09/2013 & 1.5037 & 0.0282 & 0.8494 & -0.5321 & 1.2835 \\
$31 / 10 / 2013$ to 31/05/2018 & -0.1949 & 0.4021 & 1.1691 & 0.3132 \\
\hline
\end{tabular}

